\title{
Jeopardy of COVID-19: Rechecking the Perks of Phytotherapeutic Interventions
}

\author{
Priyanka Saha ${ }^{1}$, Subhankar Bose ${ }^{1}$, Amit Kumar Srivastava ${ }^{1}$, Anis Ahmad Chaudhary ${ }^{2}$ (D) Rajiv Lall ${ }^{3}$ \\ and Sahdeo Prasad ${ }^{3, *}$ \\ 1 Cancer Biology \& Inflammatory Disorder Division, CSIR-Indian Institute of Chemical Biology, \\ Kolkata 700032, WB, India; priaz12@rediffmail.com (P.S.); sbose33186@gmail.com (S.B.); \\ amit@iicb.res.in (A.K.S.) \\ 2 Department of Biology, College of Science, Imam Mohammad Ibn Saud Islamic University (IMSUI), \\ Riyadh 11623, Saudi Arabia; aachaudhary@imamu.edu.sa \\ 3 Noble Pharma, LLC, 4602 Domain Drive, Menomonie, WI 54751, USA; lallr@vets-plus.com \\ * Correspondence: spbiotech@gmail.com or sahdeop@noblepharmallc.com; Tel.: +1-715-231-1234; \\ Fax: +1-715-231-1235
}

Citation: Saha, P.; Bose, S.; Srivastava, A.K.; Chaudhary, A.A.; Lall, R.; Prasad, S. Jeopardy of COVID-19: Rechecking the Perks of Phytotherapeutic Interventions. Molecules 2021, 26, 6783. https:// doi.org/10.3390/molecules26226783

Academic Editor:

Ramunė Morkūnienè

Received: 11 October 2021

Accepted: 4 November 2021

Published: 10 November 2021

Publisher's Note: MDPI stays neutral with regard to jurisdictional claims in published maps and institutional affiliations.

Copyright: (c) 2021 by the authors. Licensee MDPI, Basel, Switzerland. This article is an open access article distributed under the terms and conditions of the Creative Commons Attribution (CC BY) license (https:/ / creativecommons.org/licenses/by/ $4.0 /)$.

\begin{abstract}
The novel coronavirus disease (COVID-19), the reason for worldwide pandemic, has already masked around 220 countries globally. This disease is induced by Severe Acute Respiratory Syndrome-Coronavirus-2 (SARS-CoV-2). Arising environmental stress, increase in the oxidative stress level, weak immunity and lack of nutrition deteriorates the clinical status of the infected patients. Though several researches are at its peak for understanding and bringing forward effective therapeutics, yet there is no promising solution treating this disease directly. Medicinal plants and their active metabolites have always been promising in treating many clinical complications since time immemorial. Mother nature provides vivid chemical structures, which act multi-dimensionally all alone or synergistically in mitigating several diseases. Their unique antioxidant and anti-inflammatory activity with least side effects have made them more effective candidate for pharmacological studies. These medicinal plants inhibit attachment, encapsulation and replication of COVID-19 viruses by targeting various signaling molecules such as angiotensin converting enzyme-2, transmembrane serine protease 2 , spike glycoprotein, main protease etc. This property is re-examined and its potency is now used to improve the existing global health crisis. This review is an attempt to focus various antiviral activities of various noteworthy medicinal plants. Moreover, its implications as prophylactic or preventive in various secondary complications including neurological, cardiovascular, acute kidney disease, liver disease are also pinpointed in the present review. This knowledge will help emphasis on the therapeutic developments for this novel coronavirus where it can be used as alone or in combination with the repositioned drugs to combat COVID-19.
\end{abstract}

Keywords: COVID-19; medicinal plants; inflammation; antioxidant; phytotherapy

\section{Introduction}

Coronavirus disease-19 (COVID-19, also known as SARS-CoV-2) has just become the hot cake internationally. This disease turned out as a pandemic in 2019 and has affected nearly 60 million people worldwide by 2021. This medical health emergency though initially starts with a mild symptomatic condition but in later stages creates an oxygen deficient environment into the human system, inducing a severe respiratory distress [1]. Several groups of researchers are working in collaboration to understand an in-depth physiological condition of the epidemiology of this disease. Not only the virologist, but also different group of scientists has directed their studies to COVID-19 research in this situation of pandemic to understand clinical complications among suffering patients and the role of upcoming secondary diseases associated with it. For instances, viral invasion causes severe cardiac injury in many patients attacking cardiomyocytes [2]. Additionally, severe 
rheumatological illness has also been reported post infection. Vasculitis and renal dysfunction are other related complications which are reported to be common complications [3]. Acute kidney infection and associated renal diseases are other reported complications post viral infections [4]. Most importantly, further research studies are warranted to better understand the impact of various environmental, physiological, and endogenous factors in the increase of mortality rates among the infected population.

Upon studying various parameters, it was interestingly seen that oxidative stress plays a critical role in majority of patients. Oxidative stress is generally associated with all physiological anomalies in human. Several lines of evidence suggest that COVID-19 infection deteriorates in many patients with malnutrition, physiological stress and coinfections, all of which adversely alter the endogenous antioxidant machinery [5]. This cocktail factor adds to the evolving virulent mutants rapidly. Earlier studies have discussed the role of existing external factors in arising complication and thus mortality amongst the infected patients. These external factors not only include the existing environmental stress but also mental stress equally taking place in several patients due to the adverse situation of lockdown in COVID-19 [6]. The present SARS-CoV-2 and the previously known SARS$\mathrm{CoV}$ viruses are evolved due to repeated mutations causing structural changes leading to varying virulence levels. Reported mutations in the spike (S) protein, i.e., D614G of SARS-CoV-2 multiply the rate of infection rendering existing medications ineffective [7]. Repeated SARS-CoV-2 mutations have further complicated the disease landscape (Figure 1). Similarly, point mutations in the receptor-binding domain (RBD) region have been reported in recent variant; remodeling the secondary structure and consequently infectivity [8]. In SARS-CoV-2 infection, virus mutation can lower down the immunity level in the affected patient [9]. Furthermore, increased levels of ROS in the body decreases T lymphocytes affecting the adaptive immune response.

B.1.7.7

Discovered: Dec. 142020

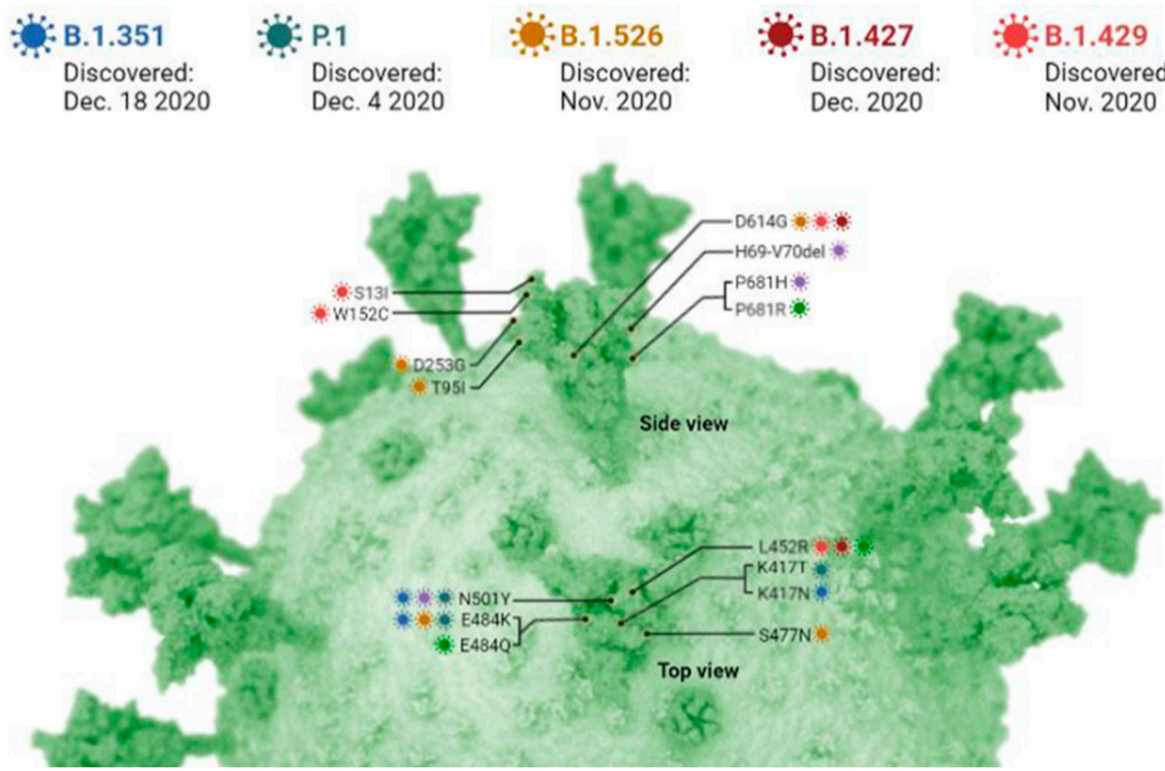

Figure 1. A snapshot of the rising variation in the strains of the SARS-CoV-2 due to mutations.

Moreover, an inappropriate immune response characterized by excessive production of proinflammatory activators have been found, which results in common symptoms in severe COVID-19 patients. Increasing immunosuppression is another important source of endogenous oxidative stress resulting in imbalance in the oxidant-antioxidant ratio in the human body [10]. This situation elevates free radicals and thus enhances the reactive oxygen species (ROS). Elevated ROS in turn alters vital physiological process, triggers inflammation and promote further viral multiplication. This can be compensated by the use of different detoxifying enzymes, exogenous antioxidants from antioxidant rich dietary 
foods and nutrients. Polyphenols, a group of natural antioxidants are proposed to be used as potential adjuvants in therapy mainly due to their anti-inflammatory effect [11,12]. Iddir et al., clearly mentioned a direct correlation of the low nutrients with COVID-19 infection where deficiency in micronutrients like Zn and Vitamin A in diets increases the infection rate. Dietary constituents like polyphenols, vitamin C, vitamin E possess anti-inflammatory and antioxidant activity, which can neutralize the induced ROS and can interact with the inflammatory mediators in the infection [13].

Many known antiviral and antimalarial drugs like remdesivir and hydroxychloroquine are broadly studied for drug repositioning against COVID-19 infection. However, traditional medicinal plants also exhibit many prophylactic or preventive effects towards this disease. Needless to pinpoint the boon of these medicinal plants and their therapeutic effects. Since the time of Charaka Samhita in 1st millennium BC and inception of Ayurveda, the use of medicinal plants has been continuing for mitigation for various ailments with minimum side effects. Many ethnomedicinal use of the plants continue to be a choice of interest across the world [14,15]. The toxicity, pharmacological properties, and mode of actions of many medicinal plants have been studied in detail. The antioxidative property of noteworthy medicinal plants like Curcuma longa, Nigella sativa, Oroxylum indicum, Echinacea purpurea, Cinchona sp., Glycyrrhiza glabra, Camellia sinensis and various other medicinal plants have always proved to be potential candidates for major microbial infections [16-18]. Additionally, anti-inflammatory and antioxidative properties makes them a choice of interest for applications in treating COVID-19 [19,20]. Present review is an attempt to highlight the efficacies of some of these medicinal plants, preparations, and their important active constituents to be used in the arising complications in COVID-19.

\section{Insight into the Pathogenesis of COVID-19}

The inception of the novel coronavirus disease pandemic has engulfed more than $3,972,783$ lives worldwide thus far [21]. There are now effective vaccines with a fairly high degree of success, however therapeutic drugs are still lacking. Also, before going into targeting this viral infection it's an utmost urgency to better reveal the COVID-19 associated pathogenesis.

The viral architecture is a simple positive double stranded RNA makeup. The virus finds its entrance through the host angiotensin converting enzyme-2 (ACE-2). This transmembrane protein is abundant in the alveolar walls, lungs, epithelial cells and gastrointestinal tract. It makes complimentary binding site for the interaction with the viral spike protein $[22,23]$. This physiological process is triggered by S1 subunit of the spike protein by acidified proteolytic cleavage and assorted by transmembrane serine protease 2 (TMPRSS2) sufficient to complete the viral internalization process. This cleaves exposes various fusion peptides and helps in the formation of bundle across the cleavage site that results in union of the viral and host cell membrane; releasing viral genetic content into the host cytoplasm [24]. Once viral content is inside the cytoplasm, the virus gains access to process its infectivity and affect the lungs initially. The process of infectivity of COVID-19 virus is shown in Figure 2. Though little is known about the role of innate immunity, there is severe rush of cytokines shower, neutrophils, interleukin and C-reactive protein (CRP) release in the system with marked decrease in lymphocytes [25]. 


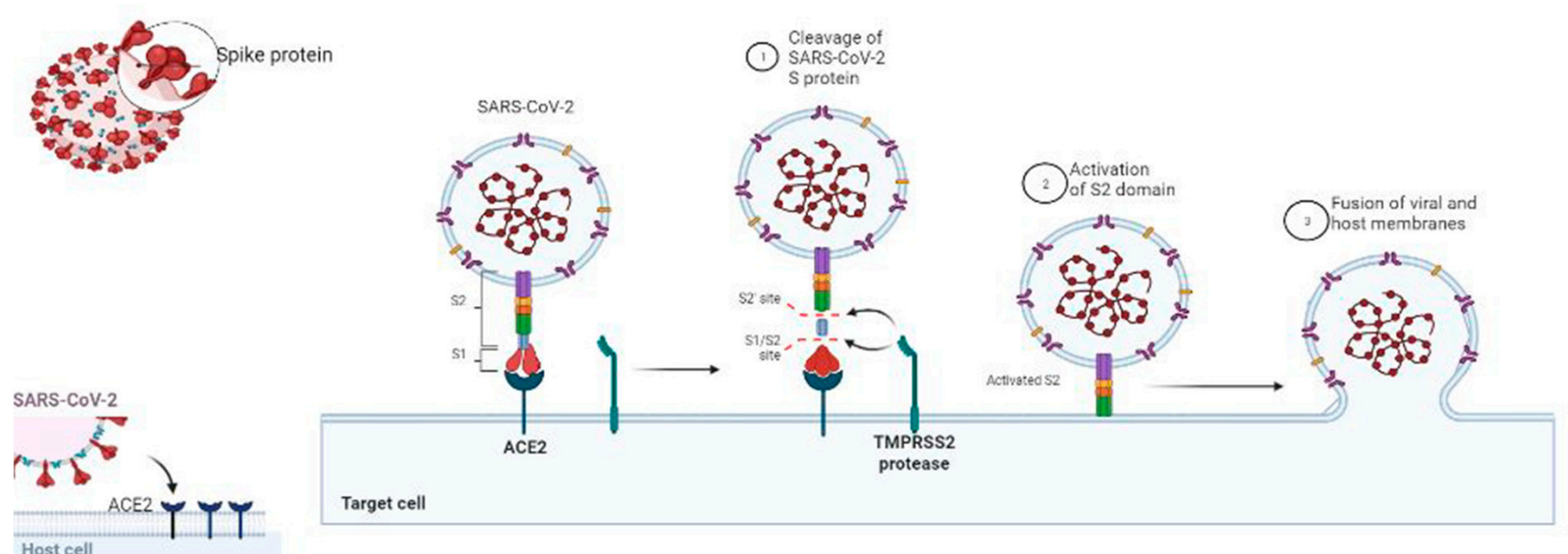

Figure 2. Pathogenesis of COVID-19 virus.

There is a high surge of IgM in the initial weeks of viral infection followed by increased IgG level in the latter phase during immunological response [26]. It multiplies within these cells then infects nearby cells, including alveolar macrophages $[27,28]$. Whole process of active response is triggered by apoptosis of the infected cells. This in turn activates proinflammatory cytokines, cell infiltration and tissue damage [29]. In COVID-19, increase of interleukins (IL-7, IL-2), inducible protein (IP)-10, granulocyte-colony stimulating factor, monocyte chemoattractant protein (MCP)-1 and tumor necrosis factor (TNF)- $\alpha$ are indicators of cytokine storm. Studies showed that a surge of cytokine storm in COVID-19 patients [29]. As entire scenario in COVID-19 patient is inter-dangled with inflammation, immunity and viral infection, anti-inflammatory activities and use of immune boosters can modulate the whole arising complexities.

\section{Potential Targets of Medicinal Plants in COVID-19 Pathogenesis}

Plant based natural products have always been a boon to cure many ailments since time immemorial. Their use as antiviral compounds is studied worldwide. Natural products in the form of nutraceuticals, medicinal foods, immune booster, antioxidants, and formulations showed antiviral activities. They have shown various modes of action including targeting viral attachment, its entry and multiplication, and suppressing inflammation [30]. Tangeretin, a citrus polymethoxyflavone compound, which is generally found in citrus peel oil is found to be greatly effective in COVID-19 treatment [31]. Similarly, other important plants like the Curcumin longa, Oroxylum indicum, Echinacea purpurea, Cinchona sp., Glycyrrhiza glabra, Ocimum sanctum, Withania somnifera and many others have reported immensely in treating COVID-19 disease. The bioactive compounds of medicinal plants can also alleviate the cytokines storm and inhibit the induced ROS, which subsequently can neutralize the inflammatory response. The role of medicinal plants and their potent molecules in different stages of COVID-19 pathogenesis intervention are summarized in Table 1. 
Table 1. Targeting COVID-19 associated molecules by medicinal plants and their bioactivities.

\begin{tabular}{|c|c|c|c|}
\hline Medicinal Plants & Plant Active Compound & Antiviral Activity & References \\
\hline Citrus aurantium & Hesperidin & Inhibition of main protease ( $\left.\mathrm{M}^{\mathrm{pro}}\right)$ & [32] \\
\hline Camellia sinensis & Epigallocatechin gallate & Inhibition of spike glycoprotein (S-protein) & [33] \\
\hline Linaria vulgaris & Pectolinarin & Inhibition of spike glycoprotein and $\mathrm{M}^{\text {pro }}$ & [33] \\
\hline Rhus succedanea & Rhoifolin & Inhibition of Mpro & [33] \\
\hline Coffea arabica & Epigallocatechin gallate & Inhibition of $\mathrm{M}^{\text {pro }}$ & [33] \\
\hline Cirsium japonicum & Cirsimaritin & Inhibits against $\mathrm{M}^{\text {pro }}$ & [34] \\
\hline Glycyrrhiza glabra & Glycyrrhizin & Reduces the level of TMPRSS2 & [35] \\
\hline Acalypha australis & Emodin & ACE-II Inhibitors & [36] \\
\hline Citrus reticulata & Nobeletin & ACE-II Inhibitors & {$[36]$} \\
\hline Lycoris squamigera & Lycorine & Inhibition of RdRP activity & [37] \\
\hline Stephania cepharantha & Cepharanthine & Inhibition of viral-target binding & [38] \\
\hline Citrus bergamia & Naringenin & ACE-II Inhibitors & {$[36]$} \\
\hline Justicia procumbens & Justicidin D & Inhibition of RdRP and spike protein & [39] \\
\hline Oroxylum indicum & Baicalin & ACE-II Inhibitors & [36] \\
\hline Curcuma longa & Curcumin & Inhibits against $\mathrm{M}^{\mathrm{Pro}}$ activity & [34] \\
\hline Morus alba & Moralbanone & Inhibition of SARS-3CL pro & [40] \\
\hline Linum usitatissimum & Herbacetin & Inhibits the activity of $3 \mathrm{CL}^{\text {pro }}$ & {$[41]$} \\
\hline Maclura tinctoria & Morin & Inhibition of $\mathrm{M}^{\mathrm{pro}}$ and S-protein & [33] \\
\hline Cirsium chanroenicum & Pectolinarin & Inhibition of $\mathrm{M}^{\mathrm{pro}}$ and S-protein & [33] \\
\hline Scutellaria baicalensis & Scutellarin & Inhibition of SARS-3CL pro & {$[42]$} \\
\hline Taraxacum officinale & Epitaraxerol & Inhibits viral activity & {$[43]$} \\
\hline Ginkgo biloba & Kaempferol & Inhibition of SARS-3CL ${ }^{\text {pro }}$ activity & {$[44]$} \\
\hline Berberis buxifolia & Berberine & Targets SARS-Cov-2 Mpro activity & {$[45]$} \\
\hline Phyllostachys nigra & Vitexine & Targets SARS-Cov-2 Mpro activity & {$[45]$} \\
\hline Toddalia asiatica (Linn.) Lam. & Toddacoumaquinone & Targets SARS-Cov-2 Mpro activity & {$[46]$} \\
\hline Olea europaea & Oleuropein & RdRP inhibitors & [47] \\
\hline Vitis vinifera & Resveratrol & RdRP inhibitors & [47] \\
\hline Caryophyllales sp. & Bisbenzylisoquinoline & Suppressing viral entry & {$[48]$} \\
\hline Oroxylum indicum & Baicelin & Inhibits the activity of $3 C^{\text {pro }}$ & {$[49]$} \\
\hline Tinospora cordifolia & Cordifolide A & Inhibition of $\mathrm{M}^{\mathrm{pro}}$ and S-protein & {$[50]$} \\
\hline Withania somnifera & Withanone & Inhibits the active protease $\mathrm{M}^{\text {pro }}$ & {$[51]$} \\
\hline Withania somnifera & Withanolide B & $\begin{array}{l}\text { Inhibits papain like receptor and ACE-II } \\
\text { receptor }\end{array}$ & [52] \\
\hline Origanum vulgare & Carvacrol & $\begin{array}{l}\text { Inhibits main protease }\left(\mathrm{M}^{\mathrm{pro}}\right) \text { and } \\
\text { SARS-CoV-2 entry }\end{array}$ & [53] \\
\hline Caesalpinia minax. & Bonducellpin D & Inhibition of $\mathrm{M}^{\text {pro }}$ & {$[54]$} \\
\hline Salvia officinalis L. & Rosemarinic acid & Inhibits the activity of $3 C^{2}$ pro & {$[55]$} \\
\hline Thymus vulgaris L. & Thymol & Inhibits spike glycoprotein & {$[56]$} \\
\hline Nepeta cataria & Pulegone & Inhibits spike glycoprotein & [56] \\
\hline Glycyrrhiza glabra & Glabiridin & Inhibits the main protease & [57] \\
\hline
\end{tabular}


Table 1. Cont.

\begin{tabular}{|c|c|c|c|}
\hline Medicinal Plants & Plant Active Compound & Antiviral Activity & References \\
\hline Fagopyrum esculentum & Rutin & Inhibition of the RNA dependent polymerase & [58] \\
\hline Cymbopogon winterianus & Citronellol & ACE-II Inhibitors & [59] \\
\hline Torreya nucifera L. & Bilobetin, amentoflavonone & Inhibition of $\mathrm{M}^{\text {pro }}$ & {$[60]$} \\
\hline Lindera aggregate & Linderane and linderalactone & $\begin{array}{l}\text { Inhibition of } 3 C^{\text {pro }} \\
\text { and spike protein }\end{array}$ & {$[61]$} \\
\hline Asparagus racemosus & $\begin{array}{l}\text { Asparoside-C, Asparoside-D } \\
\text { and Asparoside -F }\end{array}$ & $\begin{array}{l}\text { Inhibition of spike protein and } \\
\text { nsp } 15\end{array}$ & {$[62]$} \\
\hline Citrus reticulata & Hesperitin, hesperidin & Inhibition of $3 C L^{\text {pro }}$ & [63] \\
\hline Isatis indigotica & $\begin{array}{l}\text { Hesperitin, hesperidin, rutin, } \\
\text { phaitanthrin D }\end{array}$ & Inhibition of $3 C L^{\text {pro }}$ & {$[64,65]$} \\
\hline Cinnamomum zeylanicum & $\begin{array}{l}\text { Apigenin, geranylated } \\
\text { flavonoids }\end{array}$ & $\begin{array}{l}\text { Reduction in transcription factor NF- } \mathrm{kB} \\
\text { activation }\end{array}$ & {$[66]$} \\
\hline Panax ginseng & Polysaccharides & Immunomodulatory properties & {$[67,68]$} \\
\hline Urtica dioica & $\beta$-sitosterol, tannic acid & Inhibitor of ACE-II receptor & [69] \\
\hline Houttuynia cordata & Bavachinin, cosmosilin, & SARS-3CLproinhibition, RdRP & [70] \\
\hline Cibotium barometz & Neohesperidin & Inhibition SARS-3CL protease & [71] \\
\hline Hibiscus sabdariffa L. & $\begin{array}{c}\text { Anthocyanin. cyanidine, } \\
\text { anastatin A }\end{array}$ & Inhibition SARS-3CL protease & [72] \\
\hline Salvia officinalis & Luteolin, caffeic acid, & Inhibits viral replication & [73] \\
\hline Allium sativum & $\begin{array}{l}\text { Alliin, diayl disulfide, allicin, } \\
\text { quercetin }\end{array}$ & $\begin{array}{l}\text { Decreasing of viral infection rate and } \\
\text { interacts with } \mathrm{M}^{\text {pro }}\end{array}$ & {$[74]$} \\
\hline Mentha piperita & Terpenoids and menthol & Inhibition of acute respiratory infection & [75] \\
\hline Morus alba & $\begin{array}{c}\text { Moralbanone, mulberroside C, } \\
\text { eudraflavone B }\end{array}$ & Inhibition of viral replication & [40] \\
\hline Justicia adhatoda & $\begin{array}{l}\text { Anisotine, vasicoline, } \\
\text { pemirolast }\end{array}$ & Inhibition of RdRP & [76] \\
\hline
\end{tabular}

\subsection{Viral Attachment}

All viruses of coronavirus group generally have similar pattern of spike protein and its route of entrance into the host. SARS-CoV-2 being a class of coronavirus family follows similar trend of entrance into the host cells. Earlier many reports of active compounds and its role in blocking the entrance have been narrated critically. This is either done by lowering the expression of the ACE-II receptors in the cells or by blocking the receptors by the natural compounds. Glycyrrhiza glabra is one such important medicinal plant found effective against SARS-CoV-2. Its active components like glycyrrhizin, and Glyasperin A are reported to have antiviral activity particularly against spike and non-structural protein15 (nsp15). Molecular docking and simulation study showed higher binding efficacy of $G$. glabra extract that can inhibit the viral entry. Glyasperin A showed higher affinity towards spike glycoprotein [77]. Glycyrrhizic acid, another important compound of this medicinal plant has reported as protective agent in COVID-19 infection. Active compounds like Samarcadin, Femesiferol C, Famesiferol A, and Galbanic acid from Ferula asafetida have intensive binding affinities for ACE2 receptor [78]. Epigallocatechin gallate, common compound found in the green tea found potential against spike protein [79]. 


\subsection{Encapsulation, Replication of the Virus and Viral Protease}

In order to complete viral lifecycle, they involve the attachment to the active region of the host ACE-II receptor using the various virion surface glycoproteins. The entry mechanism of SARS CoV-2 depends primarily on TMPRSS2 and furin moieties, along with ACE-II receptor [80]. Therefore, inhibiting TMPRSS2 can be an effective treatment strategy. Another important protease is the chymotrypsin-like protease (3CLpro), which assists in the viral cleavage of already entered host cellular virus. It plays an important role in COVID-19 replication process [81]. Medicinal plant polyphenols, terpenoids and alkaloids can inhibit COVID-19 replication by targeting the activity of papain-like protease, 3CLpro, and fusion of the $\mathrm{S}$ protein of coronaviruses. Polyphenols inhibit signaling pathway responsible for these protease productions. Dietary polyphenols like chlorogenic acid, trigolnelline, caffeine, flavan-3-ols comprised in fractionated coffee, provide a natural source of antioxidants and interfere replication process of viral multiplications.

Additionally, the ability of the theaflavin, a component of black tea, in inhibiting the RNA dependent RNA polymerase (RdRP) active site is well documented in many recent works on COVID-19 research [82]. Bioactive compounds like vanicoside B, resveratrol, epicatechin, emodin, piceid, epicatechin from various medicinal plants including Reynoutria japonica and Reynoutria sachalinensis was found effective against the main protease (Mpro) [83]. Nimbin, gedunin, and ginsenosides, important constituents of Panax ginseng, Zingiber officinale, Ocimum basilicum are potential inhibitors of the main protease required for viral replication process of coronaviruses [84]. Punicalagin and punicalin, important compounds from Punica granatum peel extracts are reported to inhibit TMPRSS2, and ACE-II significantly [85]. Andrographis paniculata is reported to inhibit three potential key targets, papain-like receptors (PLpro), spike glycoprotein and the RdRp, which mediate the viral replication process. Neoandrographolide and 14-deoxy andrographolide, other active compounds of $A$. paniculata have shown to decrease 3CLpro and PLpro significantly [86].

Quercetin, the active flavanol common in many of the medicinal plants contains five hydroxyl moieties in its pharmacophoric region, which interferes and creates a hindrance in the early stages of the viral infections. It is usually achieved by blocking the angiotensinconverting enzyme quite significantly. The combinatorial activity of quercetin with zinc has also been reported where zinc has a role in the suppression of RdRp [87]. Some of the other important bioactive compounds having a direct role in inhibiting SARS-CoV-2 infection is briefly summarized in Table 1. Nigella sativa is another pharmacologically important plant, which contains a well-known bioactive principle thymoquinone. Being smaller in structure, this hydrophobic molecule aptly fits into the lipophilic envelope of SARS-CoV-2 inhibiting its entry and thereby replication [88].

\subsection{Inflammation}

COVID patients have surge of inflammation that is caused by increased macrophages, inflammasome and monocytes. Not only this, ROS also triggers the secondary inflammation that undergoes intercellular signaling. However, the exact mechanism is still being researched to understand how SARS-CoV-2 directly induces inflammation. It has been found that immune compromised patients have dysregulated NLRP3 inflammasome resulting in severe tissue damage and cytokine storm [89], indicating NLRP3 is one of the factors that mediates inflammation in these patients. This elevated inflammation further produces altered glycosylated IgG Fc tail and results in altered immune response. SARS-CoV-2 is independent to infect the monocytes resulting in the rush of production of proinflammatory cytokines in the mainstream to play its role in other secondary inflammation. Besides these various cytokines, chemokines, inflammatory transcription factors like NF- $\mathrm{kB}$, and TNF- $\alpha$ play a pivotal part in inflammation associated with COVID-19 patients [90]. 
Traditional folklore varieties of medicinal plants are reported to have anti-inflammatory activities, which can alleviate these pro-inflammatory mediators. The anti-inflammatory activity of medicinal plants can check the cytokine storm in the affected patients and inhibit viral entry and replication [30]. Tangeretin, a citrus polymethoxyflavone compound, which is generally found in citrus peel oil is found to be effective in COVID-19 treatment [31]. Cannabis sativa, which has been used for various medical purposes, has shown anti-inflammatory activity associated with COVID-19 infection [91]. C. sativa extract fraction greatly reduced cytokines IL-6, and IL-8 as well as chemokines: C-C Motif Chemokine Ligands (CCLs)-2 and CCL7 levels, in an alveolar epithelial cell [91]. Limonene, a dietary terpene, has also shown to modulate inflammatory signaling pathways by inhibiting inflammatory mediators, like chemokines, cytokines and eicosanoids. Thus, limonene can act as inhibitor of inflammation in COVID-19 pathogenesis [92]. Flavonoids have a property to modulate cytokine levels, which indicates its possible role in COVID-19 associated inflammation. As it regulates inflammatory mediators, endothelial activation, and NLRP3 inflammasome, might be useful in regulating the cytokine storm [93].

Different formulations and preparation have also demonstrated anti-inflammatory activities in COVID-19 associated inflammation. The Ayurvedic formulation, Divya-SwasariVati, was found to suppress the pro-inflammatory cytokine levels, TNF- $\alpha$ and IL- 6 both in humanized Zebrafish model [94]. ShufengJiedu capsules, an herbal drug with eight therapeutic plants, has also shown anti-inflammatory activity in the lung of HCoV-229E mouse model. It decreased inflammatory factors like the IL-10, TNF- $\alpha$, IFN- $\gamma$ and IL-6 in the lung [95]. Thus, COVID-19 mediated inflammation can be suppressed by traditional medicine formulations.

\subsection{Oxidative Stress}

Plants bestow antioxidant activities in a multifaceted manner, where their active ingredients work alone or in synergy to clear reactive oxygen species mainly by neutralizing them [10]. Many natural compounds were found to be efficient in earlier SARS related infections. Some of the phytocompounds were reported to inhibit the viral helicases rendering them ineffective. Several other notable plants including Boerhavia procumbens, Cistanche tubulosa, Euphorbia hirta, Hyoscyamus niger, Capparis spinosa L., Carum copticum, which not only decrease the inflammasomes in viral infection but also alleviate the level of ROS built due to cytokine storm [96]. Number of antioxidant molecules possess inhibitory function against inflammation, and viral infections. Astaxanthin, a known keto carotenoid also reported for its antioxidative efficacy in COVID-19 treatment. The polar moiety in the structure can leach the free radicals in and outside the cell membrane. This in turn enhances the process of attenuation of the stress mediated pathways in COVID-19 disease [97]. Similarly, the antiviral activities of two important antioxidant molecules, theaflavin and epigallocatechin-3-gallate (EGCG) are also reported to inhibit 3CLpro [98,99]. This explains the antioxidant medicinal plants not only lower the internal ROS but can directly interfere with the viral replications by modifying different helicases and proteases.

\subsection{Immune Response}

Immunity gets compromised in the later stages of this novel coronavirus disease. The decreased immune response causes increased secondary complications and resulting in organ failure in the suffering patients. Medicinal plants have always been used as a combinatorial medicine with other phytochemicals. Their antioxidative efficacy boosts up the immunity level in the patients to minimize further complexities in the COVID-19 disease. Ginseng plant has immunostimulating properties. They can induce cytokine productions activating the macrophages and enhancing the antibody productions [100]. Achyranthes root popularly called the Chinese yam also reported to increase the antibody productions [101]. Many recent researches on tea polyphenol showed its efficacy to modulate and augment innate immunity to prevent COVID-19 [102]. Plant based rich fiber diet are found to be beneficial, as it enriches the intestinal and gut microbiome of the host 
which enhances immunity significantly. This enhanced immunity has shown to be resulted in better prognosis of patients with COVID-19 [103].

Compounds derived from Allium sativum (garlic) have been reported to alleviate cytokine level and reverse the immunological abnormalities to comparatively safer situation in COVID-19 patients. Thus, A. sativum can be an important plant against SARS-CoV-2 infection [104]. Besides these, several other medicinal plants including Echinacea spp., Boswellia spp., Glycyrrhiza spp., Curcuma longa, medicinal fungi, Pelargonium sidoides and Sambucus spp. are documented with immunomodulatory, immunostimulatory, and antiinflammatory effects. These immune responsive properties of medicinal plants can help to prevent the viral infections [105]. Thus, these natural immune boosters can help improve various complications associated with the COVID-19 disease.

\section{Effect of Medicinal Plants in COVID-19 Associated Secondary Diseases}

It is seen in many cases that COVID-19 patients experiences post-COVID complications. However, most of the patients recover in 1-2 weeks and have fairly any emerging complications. Post-COVID conditions are wide range of complications of different organs including but not limited to lungs, liver, kidney, heart, brain (Figure 3) that patients can experience several weeks after infection. Some of the post-COVID conditions with their phytotherapy are described below (Table 2).

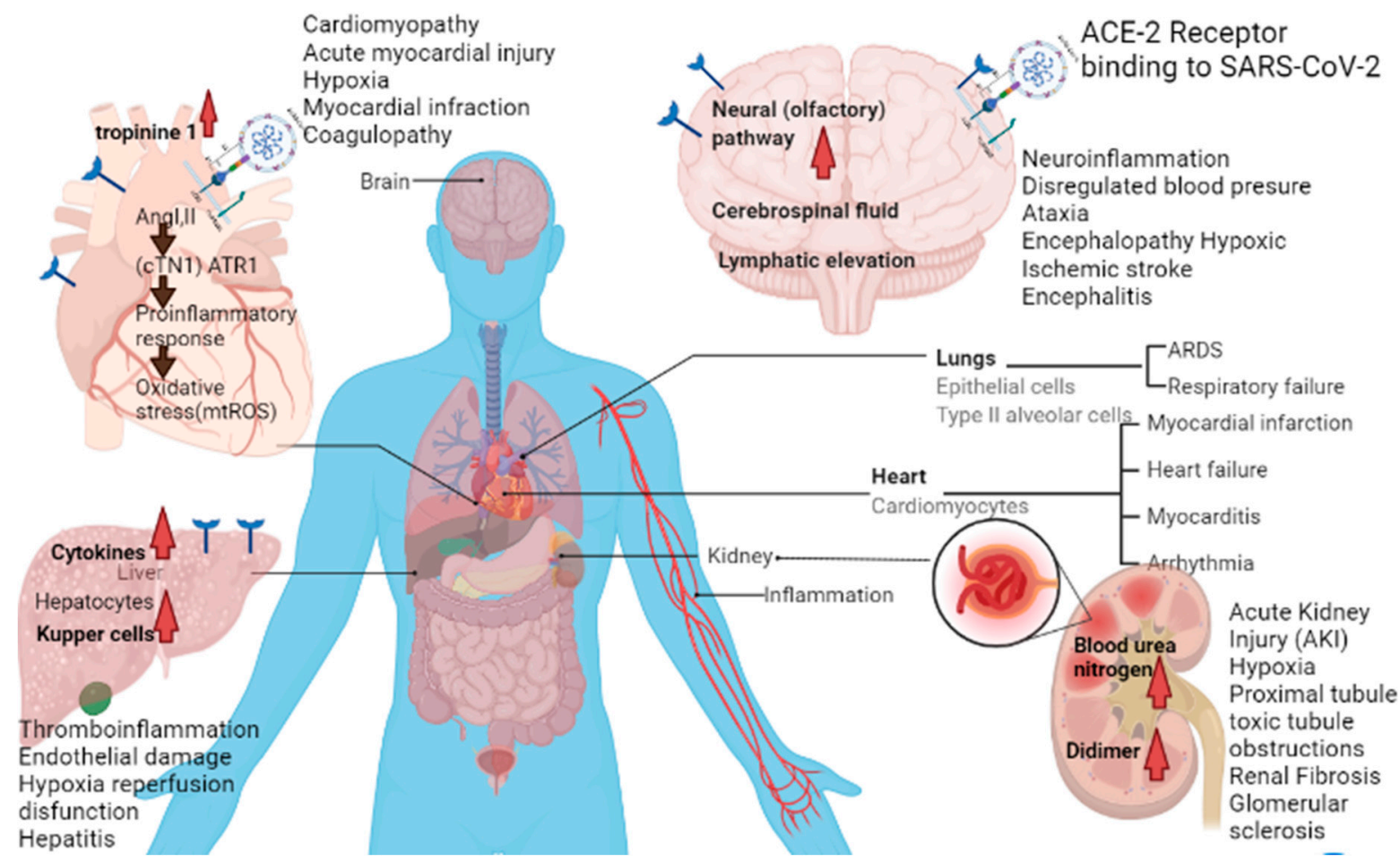

Figure 3. Post-COVID-19 conditions that may occur in different organs. 
Table 2. Post-COVID conditions with their phytotherapy.

\begin{tabular}{|c|c|c|c|c|c|}
\hline $\begin{array}{c}\text { Natural } \\
\text { Compounds }\end{array}$ & Source & Pathology & Mechanism & $\begin{array}{c}\text { Effective } \\
\text { Concentration }\end{array}$ & References \\
\hline \multicolumn{6}{|c|}{ Kidney damage } \\
\hline Poricoic acid ZA & Poriacocos & Renal fibrosis (RF) & $\begin{array}{l}\text { Inhibits Smad2/3 } \\
\text { phosphorylation }\end{array}$ & $10 \mu \mathrm{M}$ & [106] \\
\hline poricoic acid ZG & Poriacocos & $\mathrm{RF}$ & $\begin{array}{l}\text { Inhibits Smad3 and alter } \\
\text { TGF- } \beta \text { /Smad signaling }\end{array}$ & $10 \mu \mathrm{M}$ & [107] \\
\hline poricoic acid ZH & Poriacocos & RF & $\begin{array}{c}\text { Inhibits Wnt or } \\
\beta \text {-catenin signaling }\end{array}$ & $10 \mu \mathrm{M}$ & [107] \\
\hline 25-O-methylalisol & Alisma rhizoma & RF & $\begin{array}{c}\text { Inhibits Wnt or } \\
\beta \text {-catenin signaling }\end{array}$ & $10 \mu \mathrm{M}$ & [108] \\
\hline Tanshinone IIA & Salvia multiorrhiza & $\begin{array}{l}\text { Acute kidney } \\
\text { injury }\end{array}$ & $\begin{array}{l}\text { Inhibits TGF- } \beta 1 \text { and } \\
\text { MCP-1 expression }\end{array}$ & $15 \mathrm{mg} / \mathrm{kg}$ & [109] \\
\hline Leonurine & Leonurus spp. & RF & $\begin{array}{l}\text { Inhibits TGF- } \beta / \text { Smad } \\
\text { pathway }\end{array}$ & $50 \mathrm{mg} / \mathrm{kg} /$ day & [110] \\
\hline Salvianolic acid A & Salvia multiorrhiza & RF & $\begin{array}{l}\text { Inhibits TGF- } \beta 1 / \text { Smad } \\
\text { signaling and } \\
\text { inflammatory cytokines }\end{array}$ & $17.1 \mathrm{mg} / \mathrm{kg}$ & [111] \\
\hline Ligustrazine & Ligusticum striatum & RF & Inhibits TGF- $\beta$ pathway & $80 \mathrm{mg} / \mathrm{kg}$ & [112] \\
\hline Saikosaponin-D & Bupleurum falcatum & Oxidative stress & $\begin{array}{c}\text { Increases antioxidant } \\
\text { proteins CAT, SOD1, } \\
\text { HSP72 and GPx-1 }\end{array}$ & $3 \mu \mathrm{g} / \mathrm{mL}$ & [113] \\
\hline Triptolide & $\begin{array}{l}\text { Tripterygium } \\
\text { wilfordii }\end{array}$ & $\mathrm{RF}$ & $\begin{array}{l}\text { Decreases TGF- } \beta \text { and } \\
\text { MCP-1 expression }\end{array}$ & $0.6 \mathrm{mg} / \mathrm{kg}$ & [114] \\
\hline Sulforaphane & Brassica oleracea & Renal ischemia & $\begin{array}{l}\text { Increases the level of } \\
\text { Nrf2 and NQO-1 }\end{array}$ & $500 \mu \mathrm{g} / \mathrm{kg}$ & [115] \\
\hline \multicolumn{6}{|c|}{ Cardiovascular disease } \\
\hline $\begin{array}{l}\text { Malvidin-3- } \\
\text { glucoside }\end{array}$ & Vitis spp. & $\begin{array}{l}\text { Endothelial } \\
\text { dysfunction }\end{array}$ & $\begin{array}{l}\text { Reduces iNOS, COX-2, } \\
\text { IL- } 6 \text { through inhibition } \\
\text { of NF-k } \beta \text { activation }\end{array}$ & $25 \mu \mathrm{M}$ & [116] \\
\hline Sinigrin & Brassica spp. & Atheresclerosis & $\begin{array}{l}\text { Attenuates VCAM-1, } \\
\text { ICAM-1, CCL2, CCL5 } \\
\text { expression and reduces } \\
\text { LDH, LDL concentration } \\
\text { in serum }\end{array}$ & $10 \mathrm{mg} / \mathrm{kg}$ & [117] \\
\hline Delphinidin & Delphinium spp. & Heart ischemia & $\begin{array}{l}\text { Rapid reduction of } \\
\text { cytochrome c }\end{array}$ & $40 \mu \mathrm{M}$ & [118] \\
\hline Cyanidin & Vaccinium spp. & Heart ischemia & $\begin{array}{l}\text { Rapid reduction of } \\
\text { cytochrome c }\end{array}$ & $40 \mu \mathrm{M}$ & [118] \\
\hline Thymoquinone & Nigella sativa & Cardiac failure & $\begin{array}{c}\text { Decreases oxidative and } \\
\text { nitrosative stress }\end{array}$ & $200 \mathrm{mg} / \mathrm{kg}$ & [119] \\
\hline Ginsenoside Rb1 & Panax spp. & Cardiac failure & $\begin{array}{l}\text { Reduces the level of } \\
\text { ANF, } \beta-\mathrm{MHC} \text {, Ang II, } \\
\text { ACE, AT1 and enhances } \\
\text { translocation of GLUT4 } \\
\text { to plasma membrane }\end{array}$ & $\begin{array}{l}35 \mathrm{mg} / \mathrm{kg} \\
70 \mathrm{mg} / \mathrm{kg}\end{array}$ & [120] \\
\hline Phlorotannin & Fucus spiralis & $\begin{array}{l}\text { High blood } \\
\text { pressure. }\end{array}$ & Inhibits ACE & $200 \mu \mathrm{g} / \mathrm{mL}$ & {$[121]$} \\
\hline
\end{tabular}


Table 2. Cont.

\begin{tabular}{|c|c|c|c|c|c|}
\hline $\begin{array}{c}\text { Natural } \\
\text { Compounds }\end{array}$ & Source & Pathology & Mechanism & $\begin{array}{c}\text { Effective } \\
\text { Concentration }\end{array}$ & References \\
\hline \multicolumn{6}{|c|}{ Cardiovascular disease } \\
\hline Oleocanthal & Olea europaea & Atherosclerosis & $\begin{array}{l}\text { Inhibition of platelet } \\
\text { aggregation mediated } \\
\text { inflammation }\end{array}$ & $\begin{array}{l}40 \mathrm{~mL} \text { of extra } \\
\text { virgin olive oil }\end{array}$ & [122] \\
\hline Barberine & Berberis spp. & $\begin{array}{l}\text { Myocardial } \\
\text { ischemia }\end{array}$ & $\begin{array}{c}\text { Decreases CK-MB, LDH, } \\
\text { TNF- } \alpha, \text { IL- } 6 \text { and regulate } \\
\text { HMGB1-TLR4 axis }\end{array}$ & $\begin{array}{l}30 \mathrm{mg} / \mathrm{kg} \\
60 \mathrm{mg} / \mathrm{kg}\end{array}$ & [123] \\
\hline Resveratrol & Vitis spp. & $\begin{array}{l}\text { Myocardial } \\
\text { ischemia }\end{array}$ & $\begin{array}{c}\text { Promotes VEGF-B/ } \\
\text { antioxidant signaling } \\
\text { pathway }\end{array}$ & $10 \mu \mathrm{M}$ & [124] \\
\hline \multicolumn{6}{|c|}{ Liver injury } \\
\hline Glycyrrhizin & Glycyrrhiza glabra & $\begin{array}{l}\text { Hepatic ischemia- } \\
\text { reperfusion }\end{array}$ & $\begin{array}{c}\text { Inhibits Gasdermin } \\
\text { D-mediated pyroptotic } \\
\text { cell death of Kupffer } \\
\text { cells }\end{array}$ & $100 \mathrm{uM}$ & [125] \\
\hline Chicoric acid & Cichorium intybus & Hepatitis B & $\begin{array}{l}\text { Block viral protein and } \\
\text { DNA replication }\end{array}$ & $100 \mu \mathrm{g} / \mathrm{mL}$ & [126] \\
\hline Curcumin & Curcuma longa & Liver cirrhosis & Reduces oxidative stress & $300 \mathrm{mg} / \mathrm{kg} /$ day & [127] \\
\hline Dieckol & Ecklonia cava & $\begin{array}{c}\text { Carbon } \\
\text { tetrachloride } \\
\text { induced liver } \\
\text { damage }\end{array}$ & $\begin{array}{c}\text { Upregulates antioxidant } \\
\text { enzymes }\end{array}$ & $25 \mathrm{mg} / \mathrm{kg}$ & [128] \\
\hline Puerarin & Pueraria lobata & $\begin{array}{c}\text { Carbon } \\
\text { tetrachloride } \\
\text { induced liver } \\
\text { damage }\end{array}$ & $\begin{array}{c}\text { Regulates } \\
\text { JNK/c-Jun/CYP7A1 } \\
\text { Pathway }\end{array}$ & $400 \mathrm{mg} / \mathrm{kg}$ & [129] \\
\hline Delphinidin & Delphinium & Hepatitis C & $\begin{array}{l}\text { Impairs viral attachment } \\
\text { to cell }\end{array}$ & $100 \mu \mathrm{M}$ & [130] \\
\hline Gallic acid & Fragaria ananassa & $\begin{array}{l}\text { Paracetamol } \\
\text { induced liver } \\
\text { damage }\end{array}$ & $\begin{array}{l}\text { Decreases TNF- } \alpha \text { and } \\
\text { lipid peroxidation levels }\end{array}$ & $100 \mathrm{mg} / \mathrm{kg}$ & [131] \\
\hline Baicalein & $\begin{array}{l}\text { Scutellaria } \\
\text { baicalensis }\end{array}$ & $\begin{array}{l}\text { Carbon } \\
\text { tetrachloride } \\
\text { induced liver } \\
\quad \text { damage }\end{array}$ & $\begin{array}{c}\text { Decreases AST and ALT } \\
\text { levels }\end{array}$ & $80 \mathrm{mg} / \mathrm{kg}$ & [132] \\
\hline Troxerutin & $\begin{array}{l}\text { Styphnolobium } \\
\text { japonicum }\end{array}$ & $\begin{array}{c}\text { Liver } \\
\text { inflammation }\end{array}$ & $\begin{array}{c}\text { Reduces oxidative stress } \\
\text { mediated } \\
\text { NAD+-depletion }\end{array}$ & $150 \mathrm{mg} / \mathrm{kg} /$ day & [133] \\
\hline \multicolumn{6}{|c|}{ Neurological disorder } \\
\hline Resveratrol & Vitis spp. & Cerebral ishchemia & $\begin{array}{l}\text { Enhances Nrf2 and } \\
\text { HO-1 expression }\end{array}$ & $30 \mathrm{mg} / \mathrm{kg}$ & [134] \\
\hline Kaempferol & Brassica oleracea & $\begin{array}{l}\text { Oxidative stress } \\
\text { induced } \\
\text { neurotoxicity }\end{array}$ & $\begin{array}{c}\text { Inhibits GSK3 } \beta \text { and } \\
\text { enhance Nrf2 expression }\end{array}$ & $21 \mathrm{mg} / \mathrm{kg}$ & [135] \\
\hline Ginkgolide & Ginkgo biloba & $\begin{array}{l}\text { Cerebral } \\
\text { ishchemia- } \\
\text { repurfusion } \\
\text { injury }\end{array}$ & $\begin{array}{c}\text { Elevates the TNF related } \\
\text { weak initiator of } \\
\text { apoptosis (TWEAK) } \\
\text { ligand }\end{array}$ & $2.5 \mathrm{~mL} / \mathrm{kg}$ & [136] \\
\hline
\end{tabular}


Table 2. Cont

\begin{tabular}{|c|c|c|c|c|c|}
\hline $\begin{array}{c}\text { Natural } \\
\text { Compounds }\end{array}$ & Source & Pathology & Mechanism & $\begin{array}{c}\text { Effective } \\
\text { Concentration }\end{array}$ & References \\
\hline \multicolumn{6}{|c|}{ Neurological disorder } \\
\hline Pterostilbene & $\begin{array}{l}\text { Pterocarpus } \\
\text { marsupium }\end{array}$ & $\begin{array}{l}\text { Oxidative stress } \\
\text { induced } \\
\text { neurotoxicity }\end{array}$ & $\begin{array}{l}\text { Acts as estrogen like } \\
\text { compound to activate } \\
\text { estrogen receptor- } \alpha \\
(\text { ER- } \alpha) \text { mediated } \\
\text { signaling }\end{array}$ & $10 \mathrm{nM}$ & [137] \\
\hline Myricanol & Myrica rubra & $\begin{array}{l}\text { Oxidative stress } \\
\text { induced } \\
\text { neurotoxicity }\end{array}$ & $\begin{array}{l}\text { Enhances Nrf2 } \\
\text { expression }\end{array}$ & $50 \mathrm{mg} / \mathrm{mL}$ & [138] \\
\hline Capsaicin & Capsicum annuum & Cerebral ischemia & $\begin{array}{l}\text { Regulates transient } \\
\text { receptor potential } \\
\text { channel vanilloid } \\
\text { subfamily member } 1 \\
\text { (VR1) }\end{array}$ & $0.2 \mathrm{mg} / \mathrm{kg}$ & [139] \\
\hline Ergothioneine & Pleurotus ostreatus & Endothelial Injury & $\begin{array}{c}\text { Decreases IL-8, IL-6, } \\
\text { TNF- } \alpha, \text { COX2 } \\
\text { expression }\end{array}$ & $10 \mu \mathrm{M}$ & [140] \\
\hline $\begin{array}{l}\text { Epigallocatechin-3- } \\
\text { gallate }\end{array}$ & Camellia sinensis & Neuroinflammation & $\begin{array}{c}\text { Alleviates the STAT3 } \\
\text { and IL-6 levels }\end{array}$ & $50 \mathrm{mg} / \mathrm{mL}$ & [141] \\
\hline $\begin{array}{l}\text { Cannabigerol\& } \\
\text { cannabidiol }\end{array}$ & Cannabis sativa & Neuroinflammation & $\begin{array}{c}\text { Reduces NF-kB } \\
\text { activation and increase } \\
\text { Nrf2 levels. }\end{array}$ & $5 \mu \mathrm{M}$ & [142] \\
\hline
\end{tabular}

\subsection{Acute Kidney Damage}

Renal symptoms including acute kidney injury (AKI) is one of the most frequently occurring COVID-19 associated secondary complications [143]. In a study with 3993 hospitalized COVID-19 patients, AKI has shown to occur in 1835 (46\%) [144]. The pathways of SARS-CoV-2 mediated kidney damage is still in process of understanding but some clinical and experimental data indicated that it may be caused by viral binding with ACE2 receptor of kidney cells considering that normal kidney cells exhibited higher expression of ACE2 receptor than lung cells [145]. After binding to ACE2 receptor the COVID-19/ACE2 complex generally takes entry to the host cell by endocytosis, those which are unable to take entry to host cell shed by ADAM Metallopeptidase Domain 17 (ADAM17) [146]. Moreover, elevated level of ADAM17 in renal tissue is thought to orchestrate angiotensin II-induced renal lesion in the chronic kidney disease patients [147].

Interestingly, kidney biopsies of Afro-American COVID-19 patients appeared to be collapsing focal segmental glomerulosclerosis with elevated level of APOL1, resulting in functional effect of podocytes due the viral replication $[148,149]$. However, the undeviating SARS-CoV-2 entry through CD147, another transmembrane receptor, instigates cyclophilin mediated renal inflammation [150]. Li et al. in a comprehensive clinical study assessed the kidney function of 193 COVID patients among which $31 \%$ of patients had increased blood urea nitrogen (BUN) level, $22 \%$ with high creatinine level and $70 \%$ with elevated level of D-dimer. The incidence of proteinuria and hematuria was also seen in many COVID-19 patients [151]. Additionally Su et al. when analyzing the renal tissue of COVID-19 infected patients found increased damage rates in proximal tubules with marked erythrocyte aggregation and vacuolization in the glomerular and peritubular capillaries [150]. There is a strong chance that post SARS-CoV-2 infection may give rise to cytokine storm including IL-6, CRP and TGF- $B$ can contribute to lung-kidney crosstalk leading to AKI [152]. A current study has directed that SARS-CoV-2 triggered immune reaction is instructed by TGF- $B$ [153]. 
Natural compounds have shown to be very helpful in the management of AKI induced by COVID-19. Quercetin, which is found in wide range of medicinal plants and dietary supplements, has found to be safe and potential candidate against AKI induced by different nephrotoxic agents. Using network pharmacology and molecular docking, it has been observed that quercetin exhibits renal protective effects on COVID-19-induced AKI through inhibiting the signaling pathways associated with apoptosis and inflammation. Quercetin also inhibits SARS-CoV-2 main protease 3CL and ACE2, suppressing the integral proteins and thus affects the viral life cycle [154]. As increased level of oxidative stress and inflammation are found in COVID-19 patients, quercetin has found to be nephroprotective by suppressing ROS and inflammation induced AKI [155].

Lingustrazine (tetramethylpyrazine), a natural product isolated from Chinese herb, significantly diminished the mRNA levels of TGF- $\beta 1$ and also inhibited the loss of cytokeratin18 expression hence attenuate renal tubulointerstitial fibrosis [112]. Another important but less explored species Salvia multiorrhiza (family Lamiaceae) commonly known as Danshen is rich in tanshinones and salvionalic acids. Tanshinone IIA is well known for modulating TGF- $\beta$ signaling pathway and anti-inflammatory effect. Using AKI model, Jiang and coworkers showed that Tanshinone IIA markedly reduces the expression of TGF- $\beta 1$ and MCP-1 [109]. Similarly, Salvianolic acid A are found to inhibit inflammatory cytokines and Smad signaling pathway and thus prove to be effective in renal fibrosis [111]. As TGF- $\beta$ and cytokines are highly expressed in kidney cells of COVID-19 patients, suppression of these molecules can help in the improvement of COVID-19 patients.

\subsection{Cardiovascular Disease}

While the clinical exemplifications of COVID-19 disease are generally subjugated by respiratory symptoms, $8-12 \%$ of total patients were diagnosed with increased levels of cardiac troponine [156]. A recent clinical case study with 21 COVID-19 patients has disclosed that $42.9 \%$ of them were found to encounter congestive heart failure [157]. Another clinical study with 187 COVID-19 patients showed that $35 \%$ of them had comorbidities like hypertension, cardiomyopathy and $28 \%$ exhibited acute myocardial injury which was characterized by high levels of cardiac troponin I (cTnI) [158]. However, there is lack of exact etiological evidence that could highlight the detailed mechanism of SARS-CoV-2 and cardiac tissue interaction. Considering that ACE2 receptor is abundantly present in myocytes may indicate the direct entry of SARS-CoV-2 into heart. The ACE2 receptor plays a critical role in neurohumoral regulation of cardiovascular system. The direct binding of SARS-CoV-2 with the cardiac ACE2 receptor seems to result in acute myocardiac injury. Upon viral entry the systemic inflammation coupled with hypoxia can alter myocardial oxygen demand-supply ratio and can also induce plaque rupture and occurrence of myocardial infarction [159].

As overexpression of ACE2 receptor along with angiotensin in heart muscle cells causes systemic inflammation and myocardiac injury in COVID-19 patients, targeting these molecules by natural compounds can relive the infection associated cardiovascular illness. Studies conducted on rat model showed that Ulmus wallichiana plant extract has ability to decrease renin, Ang II, ACE activity as well as level of inflammatory molecules, which indicates its cardioprotective effect [160]. Another phytochemical rosmarinic acid, a major active constituent of Rosmarinus officinalis, exhibited cardioprotection on myocardial infarction-induced cardiac fibrosis in rat model through the suppression of ACE and angiotensin type 1 receptor (AT1R) expression [160]. Ang II, ACE and AT1 receptor are also found to be suppressed by ginsenoside Rb1; major component of the genus Panux plant in rat model. This suppression by ginsenoside $\mathrm{Rb} 1$ led to the improvement in cardiac function as indicated by attenuation in cardiac hypertrophy and myocardial fibrosis [120]. Besides angiotensin II levels, natural compounds also exert cardioprotective by suppressing inflammatory markers. In a study, blueberry extract decreased interleukin 6, endothelin 1, malondialdehyde, and angiotensin II levels and prevented particular matter (PM2.5)induced cardiovascular damage in rats [161]. In another study, orange beverage has shown 
to increase the antioxidant levels and maintain the levels of inflammatory markers IL-6 and C-reactive protein in animal model, and thus exhibited protection against cardiovascular risk factors [162]. These studies demonstrate that phytochemicals have the ability to reduce COVID-19 infection-induced enzymes, receptors and inflammatory markers level in cardiovascular system and suppress the occurrence of myocardial injury in the patients.

\subsection{Respiratory Disease}

The notable clinical manifestation of COVID-19 includes pneumonia, severe lung inflammation and acute respiratory distress syndrome (ARDS) leading to breathing problem in affected patients. Apart from this, the severity may outstretch to a complete shutdown of lung functions and induction of sepsis. Although a large proportion of clinical and experimental research are focusing on repurposing and combinatorial use of FDA approved drugs, efforts have been also made for the search of plant derived anti-viral compounds. SARS-CoV-2 enters into human host via the ACE2 receptor, which is highly expressed in lung tissue. Besides this, inflammation of the lungs is also the main factor leading to respiratory distress in patients with severe COVID-19.

In view of this, attempts have been made to identify natural inhibitors of inflammation, ACE2 and 3CL protease. However, extract of Andrographis paniculata and its active compound andrographolide directly inhibit the infectivity of SARS-CoV-2 in lung epithelial Calu-3 cells with an $\mathrm{IC}_{50}$ of $0.036 \mu \mathrm{g} / \mathrm{mL}$ and $0.034 \mu \mathrm{M}$, respectively [163]. Further, using artificial 3D human models of various tissues including lung airway, it has been found that Cannabis sativa extracts decreases ACE2 expression levels [164]. Prunus mahaleb L. fruit also downregulates the gene expression of ACE2 and TMPRSS2 in lung epithelial H1299 cells, suggests the potential role in inhibiting SARS-CoV-2 entry in the human host [165]. Besides ACE2 protein, C. sativa has also shown to reduce IL-6, IL-8, CCL2 and CCL7, expression in the lung epithelial A549 cell line and thus anticipated to prevent or treat COVID-19 infection [91].

A formulation tri-herbs, which contains ursolic acid, withanone, withaferine, cordifolioside A, magnoflorine, withanoside IV-V, betulinic acid, rosmarinic acid, and palmatine as phyto-metabolites, attenuated the inflammatory markers such as TNF- $\alpha$ and IL-6, and decreased the NF- $\kappa \mathrm{B} / \mathrm{AP}-1$ transcriptional activity in lung cells, suggesting its potential use in SARS-CoV-2 infection [94]. ShufengJiedu formulation, which comprised of multiple medicinal plants, has shown to decrease virus load and increase immune response in the lungs of mouse model, in addition to decreasing inflammatory factors [95]. The (-)-epigallocatechin-3-gallate (EGCG), a major constituent of green tea, has also shown potential to inhibit SARS-CoV-2 life cycle. It inhibits cytokine storm-mediated lung injury, acute respiratory distress syndrome, and lung fibrosis through increasing Nrf2 and suppressing NF-кB inflammatory signalling [98].

\subsection{Neurological Disease}

The pre-Bötzinger complex (PBC) in the brain primarily functions as respiratory oscillator. It might be possible that during the infection, SARS-CoV-2 targets central nervous system and inhibits the PBC in the brainstem thus contributing respiratory breakdown [166]. In COVID-19 outbreak, the accumulating evidence of clinical research stipulate that COVID19 affected patients develop several neurological complications. Out of which are directly associated with SARS-CoV-2 infection [167]. Several clinical analysis and data obtained from patients medical record established the prevalence of headache, altered mental status, disturbance in consciousness with acute cerebrovascular disease [168-170]. A study analyzed in 219 COVID-19 patients where 10 of them (4.6\%) were found to develop acute ischemic stroke and 1 patient $(0.5 \%)$ encountered with intracerebral hemorrhage [171]. Analysis of 76 patients conducted by Scullen and coworkers where 20 patients (74\%) were diagnosed with COVID-19 associated encephalopathy and 2 (7\%) with COVID-19associated acute necrotizing encephalopathy [172]. Apart from these a very few cases of rare neurological diseases Guillain-Barré syndrome and Miller Fisher Syndrome were also 
encountered $[173,174]$. A recent comprehensive study was published in Lancet Psychiatry reported an average of 33.33\% COVID-19 patients are diagnosed with a neuropsychiatric condition in the next six months which include dementia, anxiety and depression [175].

It has been revealed that many of the traditionally used medicinal plants have the property to overcome COVID-19 associated neurological disorders. In this light, Ayurvedic plants not only boost the immunity but also directly affect the symptoms of depression or anxiety in COVID-19 patients [176]. Luteolin, present in several plants, has shown to suppress neuroinflammatory responses in COVID-19 and exhibited neuroprotective effects through various mechanisms through inhibition of various immune modulatory cells [177]. Luteolin formulation together with the antihistamine rupatadine also shown to inhibit brain fog and other neuropsychiatric symptoms that have been implicated in the pathogenesis of cytokine storms in COVID-19 patients [178].

\subsection{Liver Disease}

Generally the chronic liver disease (CLD) is correlated with immune dysregulation and inflammation, which may present a greater risk of COVID-19 mediated pathogenesis [179]. Recent shreds of evidence support the cross talk between SARS-CoV-2 infection and CLD. Some clinical studies have divulged that patient with COVID-19 symptoms are having elevated level of aspartate transferase (AST), alanine transferase (ALT), alkaline phosphatase (ALP) and gamma-glutamyltransferase (GGT). High level of these markers is generally correlated with liver injury [179-181]. A recent clinical report revealed that $2-11 \%$ of overall COVID-19 patients have underlying CLD and 14-53\% with COVID-19 associated hepatic dysfunction [182]. An experimental outcome by Zhao et al. suggested that SARS-CoV-2 infected human liver ductal organoids showed elevated level of viral mRNA. They further performed transcriptome analysis and found that about $51.45 \%$ of total cells expressed TMPRSS2 receptor [183]. Also, membrane less SARS-CoV-2 vesicles have been recognized in the hepatocyte's cytoplasm of two COVID-19 patients along with high expression of liver damage markers [184]. The SARS-CoV-2 mediated hypoxia and cytokine storm could also potentiate liver injury [179]. Meanwhile some other studies reported that antiviral drugs used for the support of COVID-19 patients could also induce hepatotoxicity. Drugs like remdesivir, hydroxychloroquine and acetaminophen which are being commonly used in COVID-19 patients may be responsible for liver toxicity [185-187].

Therefore, natural products could have therapeutic potential in the management of COVID-19 affected liver injury. Based on the available evidence, glycyrrhizin preparations have been shown to be a useful therapeutic agent for SARS-CoV-2 infections, especially those complicated with liver damage [188]. In a study with 147 COVID-19 patients, it was found around $38.1 \%$ had anomalous ALT level and 54.4\% had unusual AST expression. Patients had also increased serum LDH levels and decreased SOD levels. However, treatment with diammonium glycyrrhizinate preparation alleviated the abnormal liver enzyme activities in non-critical COVID-19 patients [189]. It's another preparation Diammonium glycyrrhizinate has shown to reduce acute liver injury in patients with COVID-19 [190]. Further, a study on EGYVIR (combined formulation of black pepper and curcumin extracts) has shown that it inhibits COVID-19 infection-associated inflammatory NF- $\mathrm{kB}$ factor and cytokine storm in hepatic Huh-7 cell line [191]. Thus, natural compounds have the potential to hinder the production of inflammatory factors and improve the liver enzyme activities. Therefore, the effect of these pharmaceutically important plants and their active isolates could be also explored for the management of COVID-19 associated liver disease.

\subsection{Others}

Besides aforementioned secondary and post COVID-19 disease, many patients continue to experience symptoms such as anxiety, depression, fatigue, insomnia and also muscular sprain. However, facts from pre-pandemic observational and other related studies suggested that a nutraceutical may provide benefit to the patients with COVID-19 in managing these disorders [192] Ayurvedic medicines have also found to beneficial in 
curing COVID-19 associated symptoms [193]. Korean medicine was also found to be effective in managing COVID-19 associated symptoms. In a clinical trial with COVID-19 patients, treatment of Kyung-Ok-Ko $(n=2285)$ herbal medicine, and QingfeiPaidu decoction $(n=2053)$ led to improve on COVID-19-related symptoms like dry cough, headache, muscle pain, sore throat, dyspnea and loss of appetite. As corticosteroids have been administrated to severe patients with COVID-19, resulted in osteonecrosis of the femoral head $(\mathrm{ONFH})$ disabling complication among convalescent SARS patients. However, Chinese herbal Huo-Gu formula therapy demonstrated beneficial effects on preventing femoral head collapse, delaying total hip arthroplasty, and maintaining physical function caused by ONFH in COVID-19 patients [194]. Besides these, several traditional medicines and herbal preparations have been used as therapeutic option for treating COVID-19 associated symptoms and post recovery.

\section{Conclusions}

Hardly any country remains untouched by the menace of COVID-19 pandemic and its deleterious outcome. In this situation of crisis, it is utmost necessary to control the present ongoing condition. Where bringing out newer drugs is relatively harder it is very urgent to bring about a quick remedy for this disease. Medicinal plants have always been a huge repository presenting vivid range of natural products having both prophylactic and preventive activity against many serious complications. Where pooling the entire bioactivity data is a tedious job amidst lots of existing extracts variation and lack of proper standardization of the purified extracts, so direct anti-inflammatory, antioxidant and antiviral activity of such medicinal plants can be directed to understand their protective role in the mitigation of the various prevailing secondary complications associated with the COVID-19. Important plants like Withania somnifera, Ginkgo biloba, Citrus reticulata, Camellia sinensis, Glycyrrhiza glabra, Coffea arabica mentioned here in this review are rich in antioxidant and inflammatory activity. They show inhibitory action against integral proteins of SARS-CoV-2, whether it's the spike protein or the inhibition of the RNA dependent polymerase, or papain like receptor and ACE-II receptor. So, further in-depth study on these medicinal plants with antioxidant and inflammatory activities can be studied for more putative compounds that can be promising leads in the development of newer therapeutic drugs.

Author Contributions: S.P. contributed to the concept, design and to the writing of the manuscript. P.S. contributed to literature search, writing, and preparation of tables and figures. S.B. contributed to the writing and preparation of tables. A.K.S., A.A.C., R.L., reviewed and provided feedback in the manuscript designing and writing. All authors have read and agreed to the published version of the manuscript.

Funding: This research received no external funding.

Institutional Review Board Statement: Not applicable.

Informed Consent Statement: Not applicable.

Data Availability Statement: Not applicable.

Acknowledgments: P.S. greatly acknowledges the DBT-Research Associateship of Life science and Biotechnology. S.B. is a CSIR-Junior Research Fellow. We thank Kshitij Verma for carefully proofreading the manuscript. We also thank Ashish Pandey, Ayurvedic medical practitioner, Palia, UP, India for his suggestions and discussion on this topic.

Conflicts of Interest: The authors declare no conflict of interest. 


\section{References}

1. Ghosh, B.; Biswas, A. Status evaluation of provinces affected by COVID-19: A qualitative assessment using fuzzy system. Appl. Soft Comput. 2021, 109, 107540. [CrossRef] [PubMed]

2. Lee, C.C.; Ali, K.; Connell, D.; Mordi, I.R.; George, J.; Lang, E.M.; Lang, C.C. COVID-19-Associated Cardiovascular Complications. Diseases 2021, 9, 47. [CrossRef]

3. Zacharias, H.; Dubey, S.; Koduri, G.; D’Cruz, D. Rheumatological complications of Covid 19. Autoimmun. Rev. 2021, $20,102883$. [CrossRef] [PubMed]

4. Qian, J.-Y.; Wang, B.; Liu, B.-C. Acute kidney injury in the 2019 novel coronavirus disease. Kidney Dis. 2020, 6, 318-323. [CrossRef] [PubMed]

5. Darenskaya, M.; Kolesnikova, L.; Kolesnikov, S. The Association of Respiratory Viruses with Oxidative Stress and Antioxidants. Implications for the COVID-19 Pandemic. Curr. Pharm. Des. 2021, 27, 1618-1627. [CrossRef] [PubMed]

6. Mehri, F.; Rahbar, A.H.; Ghane, E.T.; Souri, B.; Esfahani, M. The comparison of oxidative markers between Covid-19 patients and healthy subjects: Oxidative stress and Covid-19. Arch. Med. Res. 2021. [CrossRef]

7. Esper, F.P.; Cheng, Y.-W.; Adhikari, T.M.; Tu, Z.J.; Li, D.; Li, E.A.; Farkas, D.H.; Procop, G.W.; Ko, J.S.; Chan, T.A. Genomic epidemiology of SARS-CoV-2 infection during the initial pandemic wave and association with disease severity. JAMA Netw. Open 2021, 4, e217746. [CrossRef] [PubMed]

8. Saha, P.; Banerjee, A.K.; Tripathi, P.P.; Srivastava, A.K.; Ray, U. A virus that has gone viral: Amino acid mutation in S protein of Indian isolate of Coronavirus COVID-19 might impact receptor binding, and thus, infectivity. Biosci. Rep. 2020, 40, BSR20201312. [CrossRef] [PubMed]

9. Garcia-Beltran, W.F.; Lam, E.C.; Astudillo, M.G.; Yang, D.; Miller, T.E.; Feldman, J.; Hauser, B.M.; Caradonna, T.M.; Clayton, K.L.; Nitido, A.D. COVID-19-neutralizing antibodies predict disease severity and survival. Cell 2021, 184, 476-488.e11. [CrossRef] [PubMed]

10. Ntyonga-Pono, M.-P. COVID-19 infection and oxidative stress: An under-explored approach for prevention and treatment? Pan Afr. Med. J. 2020, 35 (Suppl. 2), 12. [CrossRef] [PubMed]

11. Biswas, S.K. Does the interdependence between oxidative stress and inflammation explain the antioxidant paradox? Oxid. Med. Cell. Longev. 2016, 2016, 5698931. [CrossRef]

12. Hussain, T.; Tan, B.; Yin, Y.; Blachier, F.; Tossou, M.C.; Rahu, N. Oxidative stress and inflammation: What polyphenols can do for us? Oxid. Med Cell. Longev. 2016, 2016, 7432797. [CrossRef]

13. Iddir, M.; Brito, A.; Dingeo, G.; Fernandez Del Campo, S.S.; Samouda, H.; La Frano, M.R.; Bohn, T. Strengthening the immune system and reducing inflammation and oxidative stress through diet and nutrition: Considerations during the COVID-19 crisis. Nutrients 2020, 12, 1562. [CrossRef] [PubMed]

14. Shakya, A.K. Medicinal plants: Future source of new drugs. Int. J. Herb. Med. 2016, 4, 59-64.

15. Sen, B. Potentiality and possibility of Medicinal Plants on Ayurvedic Principle in prevention and treatment of COVID-19. J. Ayu. Herb. Med. 2020, 6, 100-107. [CrossRef]

16. Zhang, L.; Ravipati, A.S.; Koyyalamudi, S.R.; Jeong, S.C.; Reddy, N.; Smith, P.T.; Bartlett, J.; Shanmugam, K.; Münch, G.; Wu, M. Antioxidant and anti-inflammatory activities of selected medicinal plants containing phenolic and flavonoid compounds. J. Agric. Food Chem. 2011, 59, 12361-12367. [CrossRef] [PubMed]

17. Saha, P.; Choudhury, P.R.; Das, S.; Talukdar, A.D.; Choudhury, M.D. In vitro antioxidant activity of bark extracts of Oroxylum indicum (L.) vent. Asian J. Pharm. Clin. Res. 2017, 10, 263-266. [CrossRef]

18. Atawodi, S. Antioxidant potential of African medicinal plants. Afr. J. Biotechnol. 2005, 4, 128-133.

19. Murugesan, D.; Deviponnuswamy, R. Potential anti-inflammatory medicinal plants-a review. Int. J. Pharm. Pharm. Sci. 2014, 6, 43-49.

20. Siriwatanametanon, N.; Fiebich, B.L.; Efferth, T.; Prieto, J.M.; Heinrich, M. Traditionally used Thai medicinal plants: In vitro anti-inflammatory, anticancer and antioxidant activities. J. Ethnopharmacol. 2010, 130, 196-207. [CrossRef] [PubMed]

21. Galloway, S.E.; Paul, P.; MacCannell, D.R.; Johansson, M.A.; Brooks, J.T.; MacNeil, A.; Slayton, R.B.; Tong, S.; Silk, B.J.; Armstrong, G.L.; et al. Emergence of SARS-CoV-2 b. 1.1. 7 lineage-United States, December 29, 2020-January 12, 2021. Morb. Mortal. Wkly. Rep. 2021, 70, 95-99. [CrossRef] [PubMed]

22. Hamming, I.; Timens, W.; Bulthuis, M.; Lely, A.; Navis, G.V.; van Goor, H. Ireland, Tissue distribution of ACE2 protein, the functional receptor for SARS coronavirus. A first step in understanding SARS pathogenesis. J. Pathol. 2004, 203, 631-637. [CrossRef] [PubMed]

23. Bourgonje, A.R.; Abdulle, A.E.; Timens, W.; Hillebrands, J.L.; Navis, G.J.; Gordijn, S.J.; Bolling, M.C.; Dijkstra, G.; Voors, A.A.; Osterhaus, A.D. Angiotensin-converting enzyme 2 (ACE2), SARS-CoV-2 and the pathophysiology of coronavirus disease 2019 (COVID-19). J. Pathol. 2020, 251, 228-248. [CrossRef]

24. Rahman, N.; Basharat, Z.; Yousuf, M.; Castaldo, G.; Rastrelli, L.; Khan, H. Virtual screening of natural products against type II transmembrane serine protease (TMPRSS2), the priming agent of coronavirus 2 (SARS-CoV-2). Molecules 2020, 25, 2271. [CrossRef] [PubMed]

25. Karcioglu, O.; Afacan, G.; Ozkaya, B.; Yilmaz, E.; Ersan, E.; Yeniocak, S.; Hosseinzadeh, M. Cytokine storm, corticosteroids and interleukin-6 receptor antibodies in context of antiinflammatory treatment in COVID-19. J. Pharm. Res. Int. 2020, 32, 67-75. [CrossRef] 
26. Ma, H.; Zeng, W.; He, H.; Zhao, D.; Jiang, D.; Zhou, P.; Cheng, L.; Li, Y.; Ma, X.; Jin, T. Serum IgA, IgM, and IgG responses in COVID-19. Cell. Mol. Immunol. 2020, 17, 773-775. [CrossRef]

27. Remy, K.E.; Mazer, M.; Striker, D.A.; Ellebedy, A.H.; Walton, A.H.; Unsinger, J.; Blood, T.M.; Mudd, P.A.; Yi, D.J.; Mannion, D.A. Severe immunosuppression and not a cytokine storm characterizes COVID-19 infections. JCI Insight 2020, 5, e140329. [CrossRef] [PubMed]

28. Soy, M.; Keser, G.; Atagündüz, P.; Tabak, F.; Atagündüz, I.; Kayhan, S. Cytokine storm in COVID-19: Pathogenesis and overview of anti-inflammatory agents used in treatment. Clin. Rheumatol. 2020, 39, 2085-2094. [CrossRef] [PubMed]

29. Vaninov, N. In the eye of the COVID-19 cytokine storm. Nat. Rev. Immunol. 2020, 20, 277. [CrossRef]

30. Sun, Z.; He, G.; Huang, N.; Thilakavathy, K.; Lim, J.C.W.; Kumar, S.S.; Xiong, C. Glycyrrhizic Acid: A Natural Plant Ingredient as a Drug Candidate to Treat COVID-19. Front. Pharmacol. 2021, 12, 1740.

31. Rocha, M.N.D.; Alves, D.R.; Marinho, M.M.; Morais, S.M.d.; Marinho, E.S. Virtual screening of citrus flavonoid tangeretin: A promising pharmacological tool for the treatment and prevention of Zika fever and COVID-19. J. Comput. Biophys. Chem. 2021, 20, 283-304. [CrossRef]

32. Adem, S.; Eyupoglu, V.; Sarfraz, I.; Rasul, A.; Ali, M. Identification of potent COVID-19 main protease (Mpro) inhibitors from natural polyphenols: An in silico strategy unveils a hope against CORONA. Preprints 2020, 2020030333. [CrossRef]

33. Tallei, T.E.; Tumilaar, S.G.; Niode, N.J.; Kepel, B.J.; Idroes, R.; Effendi, Y.; Sakib, S.A.; Emran, T.B. Potential of plant bioactive compounds as SARS-CoV-2 main protease (Mpro) and spike (S) glycoprotein inhibitors: A molecular docking study. Scientifica 2020, 2020, 6307457. [CrossRef] [PubMed]

34. Omar, S.; Bouziane, I.; Bouslama, Z.; Djemel, A. In-silico identification of potent inhibitors of COVID-19 main protease (Mpro) and angiotensin converting enzyme 2 (ACE2) from natural products: Quercetin, hispidulin, and cirsimaritin exhibited better potential inhibition than hydroxy-chloroquine against COVID-19 main protease active site and ACE2. ChemRxiv 2020. Version 1. [CrossRef]

35. Murck, H. Symptomatic protective action of glycyrrhizin (licorice) in COVID-19 infection? Front. Immunol. 2020, 11, 1239. [CrossRef]

36. Dabaghian, F.; Khanavi, M.; Zarshenas, M.M. Bioactive compounds with possible inhibitory activity of Angiotensin-Converting Enzyme-II; a gate to manage and prevent COVID-19. Med. Hypotheses 2020, 143, 109841. [CrossRef] [PubMed]

37. Jin, Y.-H.; Min, J.S.; Jeon, S.; Lee, J.; Kim, S.; Park, T.; Park, D.; Jang, M.S.; Park, C.M.; Song, J. Lycorine, a non-nucleoside RNA dependent RNA polymerase inhibitor, as potential treatment for emerging coronavirus infections. Phytomed 2021, 86, 153440. [CrossRef] [PubMed]

38. Ohashi, H.; Watashi, K.; Saso, W.; Shionoya, K.; Iwanami, S.; Hirokawa, T.; Shirai, T.; Kanaya, S.; Ito, Y.; Kim, K.S. Potential anti-COVID-19 agents, cepharanthine and nelfinavir, and their usage for combination treatment. iScience 2021, $24,102367$. [CrossRef] [PubMed]

39. Gani, M.A.; Nurhan, A.D.; Maulana, S.; Siswodihardjo, S.; Shinta, D.W.; Khotib, J. Structure-based virtual screening of bioactive compounds from Indonesian medical plants against severe acute respiratory syndrome coronavirus-2. J. Adv. Pharm. Technol. Res. 2021, 12, 120-126. [PubMed]

40. Shakya, A.; Chikhale, R.V.; Bhat, H.R.; Alasmary, F.A.; Almutairi, T.M.; Ghosh, S.K.; Alhajri, H.M.; Alissa, S.A.; Nagar, S.; Islam, M.A. Pharmacoinformatics-based identification of transmembrane protease serine-2 inhibitors from Morus Alba as SARS-CoV-2 cell entry inhibitors. Mol. Divers. 2021, 1-14. [CrossRef]

41. Sawikowska, A. Meta-analysis of flavonoids with antiviral potential against coronavirus. Biom. Lett. 2020, 57, 13-22. [CrossRef]

42. Liu, H.; Ye, F.; Sun, Q.; Liang, H.; Li, C.; Li, S.; Lu, R.; Huang, B.; Tan, W.; Lai, L. Scutellaria baicalensis extract and baicalein inhibit replication of SARS-CoV-2 and its 3C-like protease in vitro. J. Enzym. Inhib. Med. Chem. 2021, 36, 497-503. [CrossRef] [PubMed]

43. Remali, J.; Aizat, W.M. A review on plant bioactive compounds and their modes of action against coronavirus infection. Front. Pharmacol. 2020, 11, 589044. [CrossRef] [PubMed]

44. Khan, A.; Heng, W.; Wang, Y.; Qiu, J.; Wei, X.; Peng, S.; Saleem, S.; Khan, M.; Ali, S.S.; Wei, D.Q. In silico and in vitro evaluation of kaempferol as a potential inhibitor of the SARS-CoV-2 main protease (3CLpro). Phytother. Res. 2021, 35, 2841-2845. [CrossRef]

45. Alagu Lakshmi, S.; Shafreen, R.M.B.; Priya, A.; Shunmugiah, K.P. Ethnomedicines of Indian origin for combating COVID-19 infection by hampering the viral replication: Using structure-based drug discovery approach. J. Biomol. Struct. Dyn. 2020, 39, 4594-4609. [CrossRef] [PubMed]

46. Chidambaram, S.K.; Ali, D.; Alarifi, S.; Radhakrishnan, S.; Akbar, I. In silico molecular docking: Evaluation of coumarin based derivatives against SARS-CoV-2. J. Biomol. Struct. Dyn. 2020, 13, 1671-1677.

47. Abd El-Aziz, N.M.; Shehata, M.G.; Eldin Awad, O.M.; El-Sohaimy, S.A. Inhibition of COVID-19 RNA-dependent RNA polymerase by natural bioactive compounds: Molecular docking analysis. Egypt. J. Chem. 2021, 64, 1989-2001.

48. He, C.-L.; Huang, L.-Y.; Wang, K.; Gu, C.-J.; Hu, J.; Zhang, G.-J.; Xu, W.; Xie, Y.-H.; Tang, N.; Huang, A.-L. Identification of bis-benzylisoquinoline alkaloids as SARS-CoV-2 entry inhibitors from a library of natural products. Signal. Transduct. Target. Ther. 2021, 6, 1-3. [CrossRef]

49. Jo, S.; Kim, S.; Kim, D.Y.; Kim, M.-S.; Shin, D.H. Flavonoids with inhibitory activity against SARS-CoV-2 3CLpro. J. Enzym. Inhib. Med. Chem. 2020, 35, 1539-1544. [CrossRef] [PubMed] 
50. Muralikumar, V.; Ramakrishnamacharya, C.; Seshachalam, C. Technology, Inhibitory effect of phytochemicals from Azadirachta indica a juss. and Tinospora cordifolia (thunb.) miers against SARS-COV-2 mpro and spike protease-An in silico analysis. Int. J. Eng. Appl. Sci. 2020, 5, 303-319.

51. Kumar, V.; Dhanjal, J.K.; Kaul, S.C.; Wadhwa, R.; Sundar, D. Withanone and caffeic acid phenethyl ester are predicted to interact with main protease (Mpro) of SARS-CoV-2 and inhibit its activity. J. Biomol. Struct. Dyn. 2020, 39, 3842-3854. [CrossRef] [PubMed]

52. Srivastava, A.; Siddiqui, S.; Ahmad, R.; Mehrotra, S.; Ahmad, B.; Srivastava, A. Exploring nature's bounty: Identification of Withania somnifera as a promising source of therapeutic agents against COVID-19 by virtual screening and in silico evaluation. J. Biomol. Struct. Dyn. 2020, 1-51. [CrossRef]

53. Javed, H.; Meeran, M.F.N.; Jha, N.K.; Ojha, S. Carvacrol, a Plant Metabolite Targeting Viral Protease (Mpro) and ACE2 in Host Cells Can Be a Possible Candidate for COVID-19. Front. Plant. Sci. 2020, 11, 601335. [CrossRef] [PubMed]

54. Gurung, A.B.; Ali, M.A.; Lee, J.; Farah, M.A.; Al-Anazi, K.M. Unravelling lead antiviral phytochemicals for the inhibition of SARS-CoV-2 Mpro enzyme through in silico approach. Life Sci. 2020, 255, 117831. [CrossRef] [PubMed]

55. Sabet, R.; Sisakht, M.; Emami, L.; Sabahi, Z. Comparison of COVID-19 Virus Main Protease Inhibition Activities of Phenolic Acids By Molecular Docking. Trends Pharmacol. Sci. 2021, 7, 117-126.

56. Kulkarni, S.A.; Nagarajan, S.K.; Ramesh, V.; Palaniyandi, V.; Selvam, S.P.; Madhavan, T. Computational evaluation of major components from plant essential oils as potent inhibitors of SARS-CoV-2 spike protein. J. Mol. Struct. 2020, 1221, 128823. [CrossRef]

57. Jamali, N.; Soureshjani, E.H.; Mobini, G.-R.; Samare-Najaf, M.; Clark, C.C.; Saffari-Chaleshtori, J. Medicinal plant compounds as promising inhibitors of coronavirus (COVID-19) main protease: An in silico study. J. Biomol. Struct. Dyn. 2021, 1-12. [CrossRef] [PubMed]

58. Al-Zahrani, A.A. Rutin as a promising inhibitor of main protease and other protein targets of Covid-19: In silico study. J. Nat. Prod. Commun. 2020, 15, 1934578X20953951. [CrossRef]

59. Senthil Kumar, K.; Gokila Vani, M.; Wang, C.-S.; Chen, C.-C.; Chen, Y.-C.; Lu, L.-P.; Huang, C.-H.; Lai, C.-S.; Wang, S.-Y. Geranium and lemon essential oils and their active compounds downregulate angiotensin-converting enzyme 2 (ACE2), a SARS-CoV-2 spike receptor-binding domain, in epithelial cells. Plants 2020, 9, 770. [CrossRef]

60. Ghosh, R.; Chakraborty, A.; Biswas, A.; Chowdhuri, S. Computer aided identification of potential SARS CoV-2 main protease inhibitors from diterpenoids and biflavonoids of Torreya nucifera leaves. J. Biomol. Struct. Dyn. 2020, 1-16. [CrossRef] [PubMed]

61. Firdiana, E.R.; Renjana, E.; Ningrum, L.W.; Angio, M.H.; Nikmatullah, M.; Rizal, S. In Silico Study of the Active Compounds of Lindera aggregata (Sims) Kosterm as Anti-coronavirus. Curr. Nutr. Food. Sci. 2021, 17, 408-416. [CrossRef]

62. Chikhale, R.V.; Sinha, S.K.; Patil, R.B.; Prasad, S.K.; Shakya, A.; Gurav, N.; Prasad, R.; Dhaswadikar, S.R.; Wanjari, M.; Gurav, S.S. In-silico investigation of phytochemicals from Asparagus racemosus as plausible antiviral agent in COVID-19. J. Biomol. Struct. Dyn. 2020, 39, 5033-5047. [CrossRef] [PubMed]

63. Cheng, L.; Zheng, W.; Li, M.; Huang, J.; Bao, S.; Xu, Q.; Ma, Z. Citrus fruits are rich in flavonoids for immunoregulation and potential targeting ACE2. Preprints 2020, 1-7. Available online: https://www.preprints.org/manuscript/202002.0313/v1 (accessed on 3 November 2021).

64. Chen, Q.; Lan, H.-Y.; Peng, W.; Rahman, K.; Liu, Q.-C.; Luan, X.; Zhang, H. Pharmacology, Isatis indigotica: A review of phytochemistry, pharmacological activities and clinical applications. J. Pharm. Pharmacol. 2021, 73, 1137-1150. [CrossRef]

65. Daglia, M.; Di Lorenzo, A.; Nabavi, S.F.; Talas, Z.S.; Nabavi, S.M. Polyphenols: Well beyond the antioxidant capacity: Gallic acid and related compounds as neuroprotective agents: You are what you eat! Curr. Pharm. Biotechnol. 2014, 15, 362-372. [CrossRef]

66. Lucas, K.; Fröhlich-Nowoisky, J.; Oppitz, N.; Ackermann, M. Cinnamon and hop extracts as potential immunomodulators for severe COVID-19 cases. Front. Plant. Sci. 2021, 12, 263. [CrossRef] [PubMed]

67. Shi, Y.-H.; Huang, Y.-F.; Wang, W.-Y.; Yang, L.; Zhou, H.; Sang, Z. Analysis on the current quality standards of Chinese materia Medica used in COVID-19 prevention and treatment. Pharmacol. Res. 2020, 160, 105074. [CrossRef]

68. Panyod, S.; Ho, C.-T.; Sheen, L.-Y. Dietary therapy and herbal medicine for COVID-19 prevention: A review and perspective. J. Tradit. Complement. Med. Mol. Divers. 2020, 10, 420-427. [CrossRef]

69. Upreti, S.; Prusty, J.S.; Pandey, S.C.; Kumar, A.; Samant, M. Identification of novel inhibitors of angiotensin-converting enzyme 2 (ACE-2) receptor from Urtica dioica to combat coronavirus disease 2019 (COVID-19). Mol. Divers. 2021, 25, 1795-1809. [CrossRef]

70. Lau, K.-M.; Lee, K.-M.; Koon, C.-M.; Cheung, C.S.-F.; Lau, C.-P.; Ho, H.-M.; Lee, M.Y.-H.; Au, S.W.-N.; Cheng, C.H.-K.; Bik-San Lau, C. Immunomodulatory and anti-SARS activities of Houttuynia cordata. J. Ethnopharmacol. 2008, 118, 79-85. [CrossRef]

71. Wen, C.-C.; Shyur, L.-F.; Jan, J.-T.; Liang, P.-H.; Kuo, C.-J.; Arulselvan, P.; Wu, J.-B.; Kuo, S.-C.; Yang, N.-S.J. Traditional Chinese medicine herbal extracts of Cibotium barometz, Gentiana scabra, Dioscorea batatas, Cassia tora, and Taxillus chinensis inhibit SARS-CoV replication. J. Tradit. Complement. Med. 2011, 1, 41-50. [CrossRef]

72. Shawky, E.; Nada, A.A.; Ibrahim, R.S. Potential role of medicinal plants and their constituents in the mitigation of SARS-CoV-2 Identifying related therapeutic targets using network pharmacology and molecular docking analyses. RSC Adv. 2020, 10, 27961-27983. [CrossRef]

73. Pamukova-Michaelson, R.; Vodenicharova, A.; Mihaylov, C. Effect of Combined Therapies on Respiratory Diseases and Covid-19. Gen. Med. 2020, 22, 59-66.

74. Khubber, S.; Hashemifesharaki, R.; Mohammadi, M.; Gharibzahedi, S.M.T. Garlic (Allium sativum L.): A potential unique therapeutic food rich in organosulfur and flavonoid compounds to fight with COVID-19. Nutr. J. 2020, 19, 1-3. [CrossRef] 
75. Zhang, D.; Zhang, B.; Lv, J.-T.; Sa, R.-N.; Zhang, X.-M.; Lin, Z.-J. The clinical benefits of Chinese patent medicines against COVID-19 based on current evidence. Pharmacol. Res. 2020, 157, 104882. [CrossRef] [PubMed]

76. Bag, A.; Bag, A. Treatment of COVID-19 patients: Justicia adhatoda leaves extract is a strong remedy for COVID-19-Case report analysis and docking based study. ChemRxiv 2020,1-7. [CrossRef]

77. Sinha, S.K.; Prasad, S.K.; Islam, M.A.; Gurav, S.S.; Patil, R.B.; AlFaris, N.A.; Aldayel, T.S.; AlKehayez, N.M.; Wabaidur, S.M.; Shakya, A. Identification of bioactive compounds from Glycyrrhiza glabra as possible inhibitor of SARS-CoV-2 spike glycoprotein and non-structural protein-15: A pharmacoinformatics study. J. Biomol. Struct. Dyn. 2021, 39, 4686-4700. [CrossRef]

78. Adhikari, B.; Marasini, B.P.; Rayamajhee, B.; Bhattarai, B.R.; Lamichhane, G.; Khadayat, K.; Adhikari, A.; Khanal, S.; Parajuli, N. Potential roles of medicinal plants for the treatment of viral diseases focusing on COVID-19: A review. Phytother. Res. 2021, 35, 1298-1312. [CrossRef] [PubMed]

79. Subbaiyan, A.; Ravichandran, K.; Singh, S.V.; Sankar, M.; Thomas, P.; Dhama, K.; Malik, Y.S.; Singh, R.K.; Chaudhuri, P. In silico molecular docking analysis targeting SARS-CoV-2 spike protein and selected herbal constituents. J. Pure Appl. Microbiol. 2020, 14, 989-998. [CrossRef]

80. Seyran, M.; Takayama, K.; Uversky, V.N.; Lundstrom, K.; Palù, G.; Sherchan, S.P.; Attrish, D.; Rezaei, N.; Aljabali, A.A.; Ghosh, S. The structural basis of accelerated host cell entry by SARS-CoV-2. FEBS Jr. 2020, 288, 5010-5020. [CrossRef]

81. Anand, K.; Ziebuhr, J.; Wadhwani, P.; Mesters, J.R.; Hilgenfeld, R.J.S. Coronavirus main proteinase (3CLpro) structure: Basis for design of anti-SARS drugs. Science 2003, 300, 1763-1767. [CrossRef]

82. Lung, J.; Lin, Y.S.; Yang, Y.H.; Chou, Y.L.; Shu, L.H.; Cheng, Y.C.; Liu, H.T.; Wu, C.Y. The potential chemical structure of anti-SARS-CoV-2 RNA-dependent RNA polymerase. J. Med. Virol. 2020, 92, 693-697. [CrossRef]

83. Nawrot-Hadzik, I.; Zmudzinski, M.; Matkowski, A.; Preissner, R.; Kęsik-Brodacka, M.; Hadzik, J.; Drag, M.; Abel, R. Reynoutria Rhizomes as a Natural Source of SARS-CoV-2 Mpro Inhibitors-Molecular Docking and In Vitro Study. Pharmaceuticals 2021, 14, 742. [CrossRef]

84. Garg, S.; Anand, A.; Lamba, Y.; Roy, A. Molecular docking analysis of selected phytochemicals against SARS-CoV-2 M pro receptor. Vegetos 2020, 33, 766-781. [CrossRef] [PubMed]

85. Suručić, R.; Tubić, B.; Stojiljković, M.P.; Djuric, D.M.; Travar, M.; Grabež, M.; Šavikin, K.; Škrbić, R. Computational study of pomegranate peel extract polyphenols as potential inhibitors of SARS-CoV-2 virus internalization. Mol. Cell. Biochem. 2021, 476, 1179-1193. [CrossRef]

86. Murugan, N.A.; Pandian, C.J.; Jeyakanthan, J.S. Computational investigation on Andrographis paniculata phytochemicals to evaluate their potency against SARS-CoV-2 in comparison to known antiviral compounds in drug trials. J. Biomol. Struct. Dyn. 2021, 39, 4415-4426. [CrossRef] [PubMed]

87. Saakre, M.; Mathew, D.; Ravisankar, V. Perspectives on plant flavonoid quercetin-based drugs for novel SARS-CoV-2. Beni-Suef Univ. J. Basic Appl. Sci. 2021, 10, 21. [CrossRef] [PubMed]

88. Elgohary, S.; Elkhodiry, A.A.; Amin, N.S.; Stein, U.; El Tayebi, H.M. Thymoquinone: A tie-breaker in SARS-CoV2-infected cancer patients? Cells 2021, 10, 302. [CrossRef]

89. van den Berg, D.F.; Te Velde, A.A. Severe COVID-19: NLRP3 inflammasome dysregulated. Front. Immunol. 2020, 11, 1580. [CrossRef]

90. Costela-Ruiz, V.J.; Illescas-Montes, R.; Puerta-Puerta, J.M.; Ruiz, C.; Melguizo-Rodríguez, L. SARS-CoV-2 infection: The role of cytokines in COVID-19 disease. Cytokine Growth Factor Rev. 2020, 54, 62-75. [CrossRef]

91. Anil, S.M.; Shalev, N.; Vinayaka, A.C.; Nadarajan, S.; Namdar, D.; Belausov, E.; Shoval, I.; Mani, K.A.; Mechrez, G.; Koltai, H. Cannabis compounds exhibit anti-inflammatory activity in vitro in COVID-19-related inflammation in lung epithelial cells and pro-inflammatory activity in macrophages. Sci. Rep. 2021, 11, 1-14. [CrossRef]

92. Meeran, M.N.; Arunachalam, S.; Javed, H.; Sharma, C.; Hashiesh, H.M.; Goyal, S.N.; Jha, N.K.; Ojha, S. Can limonene be a possible candidate for evaluation as an agent or adjuvant against infection, immunity, and inflammation in COVID-19? Heliyon 2020, 7, e05703. [CrossRef] [PubMed]

93. Liskova, A.; Samec, M.; Koklesova, L.; Samuel, S.M.; Zhai, K.; Al-Ishaq, R.K.; Abotaleb, M.; Nosal, V.; Kajo, K.; Ashrafizadeh, M. Flavonoids against the SARS-CoV-2 induced inflammatory storm. Biomed. Pharmacother. 2021, 138, 111430. [CrossRef] [PubMed]

94. Balkrishna, A.; Solleti, S.K.; Verma, S.; Varshney, A. Application of humanized zebrafish model in the suppression of SARS-CoV-2 spike protein induced pathology by tri-herbal medicine coronil via cytokine modulation. Molecules 2020, 25, 5091. [CrossRef] [PubMed]

95. Lu, X.; Yujing, S.; Jie, S.; Friedemann, T.; Zhenggang, T.; Lu, Y.; Yun, L.; Lv, Y.; Ronghua, Z.; Zihan, G. Shufeng Jiedu, a promising herbal therapy for moderate COVID-19: Antiviral and anti-inflammatory properties, pathways of bioactive compounds, and a clinical real-world pragmatic study. Phytomedicine 2021, 85, 153390.

96. Khan, T.; Khan, M.A.; Ullah, N.; Nadhman, A.J.B.; Biotechnology, A. Therapeutic potential of medicinal plants against COVID-19: The role of antiviral medicinal metabolites. Biocatal. Agric. Biotechnol. 2020, 31, 101890. [CrossRef]

97. Fakhri, S.; Nouri, Z.; Moradi, S.Z.; Farzaei, M.H. Astaxanthin, COVID-19 and immune response: Focus on oxidative stress, apoptosis and autophagy. Phytother. Res. 2020, 34, 2790-2792. [CrossRef]

98. Zhang, Z.; Zhang, X.; Bi, K.; He, Y.; Yan, W.; Yang, C.S.; Zhang, J. Potential protective mechanisms of green tea polyphenol EGCG against COVID-19. Trends Food Sci. Technol. 2021, 114, 11-24. [CrossRef] 
99. Du, A.; Zheng, R.; Disoma, C.; Li, S.; Chen, Z.; Li, S.; Liu, P.; Zhou, Y.; Shen, Y.; Liu, S. Epigallocatechin-3-gallate, an active ingredient of Traditional Chinese Medicines, inhibits the 3CLpro activity of SARS-CoV-2. Int. J. Biol. Macromol. 2021, 176, 1-12. [CrossRef]

100. Jang, K.J.; Choi, S.H.; Yu, G.J.; Hong, S.H.; Chung, Y.H.; Kim, C.H.; Yoon, H.M.; Kim, G.Y.; Kim, B.W.; Choi, Y.H. Anti-inflammatory potential of total saponins derived from the roots of Panax ginseng in lipopolysaccharide-activated RAW 264.7 macrophages. Exp. Ther. Med. 2016, 11, 1109-1115. [CrossRef]

101. Derouiche, S. Current Review on Herbal Pharmaceutical improve immune responses against COVID-19 infection. Res. J. Pharm. Dos. Technol. 2020, 12, 181-184. [CrossRef]

102. Chowdhury, P.; Barooah, A.K. Tea bioactive modulate innate immunity: In perception to COVID-19 pandemic. Front. Immunol. 2020, 11, 590716. [CrossRef] [PubMed]

103. Rishi, P.; Thakur, K.; Vij, S.; Rishi, L.; Singh, A.; Kaur, I.P.; Patel, S.K.; Lee, J.-K.; Kalia, V.C. Diet, gut microbiota and COVID-19. Indian J. Microbiol. 2020, 60, 420-429. [CrossRef] [PubMed]

104. Donma, M.M.; Donma, O. The effects of allium sativum on immunity within the scope of COVID-19 infection. Med. Hypotheses 2020, 144, 109934. [CrossRef] [PubMed]

105. Brendler, T.; Al-Harrasi, A.; Bauer, R.; Gafner, S.; Hardy, M.L.; Heinrich, M.; Hosseinzadeh, H.; Izzo, A.A.; Michaelis, M.; Nassiri-Asl, M. Botanical drugs and supplements affecting the immune response in the time of COVID-19: Implications for research and clinical practice. Phytother. Res. 2021, 35, 3013-3031. [CrossRef] [PubMed]

106. Wang, M.; Chen, D.-Q.; Wang, M.-C.; Chen, H.; Chen, L.; Liu, D.; Zhao, H.; Zhao, Y.-Y. Poricoic acid ZA, a novel RAS inhibitor, attenuates tubulo-interstitial fibrosis and podocyte injury by inhibiting TGF- $\beta$ /Smad signaling pathway. Phytomedicine 2017, 36 , 243-253. [CrossRef] [PubMed]

107. Wang, M.; Chen, D.-Q.; Chen, L.; Liu, D.; Zhao, H.; Zhang, Z.-H.; Vaziri, N.D.; Guo, Y.; Zhao, Y.-Y.; Cao, G. Novel RAS inhibitors poricoic acid ZG and poricoic acid ZH attenuate renal fibrosis via a Wnt/ $\beta$-catenin pathway and targeted phosphorylation of smad3 signaling. J. Agric. Food. Chem. 2018, 66, 1828-1842. [CrossRef]

108. Chen, H.; Yang, T.; Wang, M.-C.; Chen, D.-Q.; Yang, Y.; Zhao, Y.-Y. Novel RAS inhibitor 25-O-methylalisol F attenuates epithelialto-mesenchymal transition and tubulo-interstitial fibrosis by selectively inhibiting TGF- $\beta$-mediated Smad 3 phosphorylation. Phytomedicine 2018, 42, 207-218. [CrossRef]

109. Jiang, C.; Shao, Q.; Jin, B.; Gong, R.; Zhang, M.; Xu, B. Tanshinone IIA attenuates renal fibrosis after acute kidney injury in a mouse model through inhibition of fibrocytes recruitment. Biomed. Res. Int. 2015, 2015, 867140. [CrossRef]

110. Cheng, H.; Bo, Y.; Shen, W.; Tan, J.; Jia, Z.; Xu, C.; Li, F. Leonurine ameliorates kidney fibrosis via suppressing TGF- $\beta$ and NF- $\mathrm{kB}$ signaling pathway in UUO mice. Int. Immunopharmacol. 2015, 25, 406-415. [CrossRef]

111. Ma, Z.; Tang, Y.; Zhong, L.; Yu, K.; He, L. Anti-fibrosis and relative mechanism of salvianolic acid A on rat model with renal fibrosis. Int. J. Clin. Exp. Med. 2016, 9, 12713-12720.

112. Yuan, X.P.; Liu, L.S.; Fu, Q.; Wang, C.X. Effects of Ligustrazine on Ureteral Obstruction-induced Renal Tubulointerstitial Fibrosis Phytother. Res. 2012, 26, 697-703. [CrossRef] [PubMed]

113. Zhang, B.-Z.; Guo, X.-T.; Chen, J.-W.; Zhao, Y.; Cong, X.; Jiang, Z.-L.; Cao, R.-F.; Cui, K.; Gao, S.-S.; Tian, W.-R. Saikosaponin-D attenuates heat stress-induced oxidative damage in LLC-PK1 cells by increasing the expression of anti-oxidant enzymes and HSP72. Am. J. Chin. Med. 2014, 42, 1261-1277. [CrossRef] [PubMed]

114. Yuan, X.P.; He, X.S.; Wang, C.X.; Liu, L.S.; Fu, Q. Triptolide attenuates renal interstitial fibrosis in rats with unilateral ureteral obstruction. Nephrology 2011, 16, 200-210. [CrossRef]

115. Shokeir, A.A.; Barakat, N.; Hussein, A.M.; Awadalla, A.; Harraz, A.; Khater, S.; Hemmaid, K.; Kamal, A.I. Activation of Nrf2 by ischemic preconditioning and sulforaphane in renal ischemia/reperfusion injury: A comparative experimental study. Physiol. Res. 2015, 64, 313. [CrossRef] [PubMed]

116. Paixão, J.; Dinis, T.C.; Almeida, L.M. Malvidin-3-glucoside protects endothelial cells up-regulating endothelial NO synthase and inhibiting peroxynitrite-induced NF-kB activation. Chem. Biol. Interact. 2012, 199, 192-200. [CrossRef]

117. Jang, Y.J.; Park, B.; Lee, H.-W.; Park, H.J.; Koo, H.J.; Kim, B.O.; Sohn, E.-H.; Um, S.H.; Pyo, S. Sinigrin attenuates the progression of atherosclerosis in ApoE-/ - mice fed a high-cholesterol diet potentially by inhibiting VCAM-1 expression. Chem. Biol. Interact. 2017, 272, 28-36. [CrossRef]

118. Skemiene, K.; Rakauskaite, G.; Trumbeckaite, S.; Liobikas, J.; Brown, G.C.; Borutaite, V. Anthocyanins block ischemia-induced apoptosis in the perfused heart and support mitochondrial respiration potentially by reducing cytosolic cytochrome c. Int. $J$. Biochem. Cell Biol. 2013, 45, 23-29. [CrossRef] [PubMed]

119. Nagi, M.N.; Al-Shabanah, O.A.; Hafez, M.M.; Sayed-Ahmed, M.M. Thymoquinone supplementation attenuates cyclophosphamideinduced cardiotoxicity in rats. J. Biochem. Mol. Toxicol. 2011, 25, 135-142. [CrossRef]

120. Zheng, X.; Wang, S.; Zou, X.; Jing, Y.; Yang, R.; Li, S.; Wang, F. Ginsenoside Rb1 improves cardiac function and remodeling in heart failure. Exp. Anim. 2017, 66, 217-228. [CrossRef]

121. Paiva, L.; Lima, E.; Neto, A.I.; Baptista, J. Angiotensin I-converting enzyme (ACE) inhibitory activity of Fucus spiralis macroalgae and influence of the extracts storage temperature-A short report. J. Pharm. Biomed. Anal. 2016, 131, 503-507. [CrossRef]

122. Agrawal, K.; Melliou, E.; Li, X.; Pedersen, T.L.; Wang, S.C.; Magiatis, P.; Newman, J.W.; Holt, R.R. Oleocanthal-rich extra virgin olive oil demonstrates acute anti-platelet effects in healthy men in a randomized trial. J. Funct. Foods 2017, 36, 84-93. [CrossRef] [PubMed] 
123. Zhang, T.; Yang, S.; Du, J. Protective effects of berberine on isoproterenol-induced acute myocardial ischemia in rats through regulating HMGB1-TLR4 axis. Evid. Based Complement. Altern. Med. 2014, 2014, 849783. [CrossRef] [PubMed]

124. Yang, L.; Zhang, Y.; Zhu, M.; Zhang, Q.; Wang, X.; Wang, Y.; Zhang, J.; Li, J.; Yang, L.; Liu, J. Resveratrol attenuates myocardial ischemia/reperfusion injury through up-regulation of vascular endothelial growth factor B. Free Radic. Biol. Med. 2016, 101, 1-9. [CrossRef] [PubMed]

125. Hua, S.; Ma, M.; Fei, X.; Zhang, Y.; Gong, F.; Fang, M. Glycyrrhizin attenuates hepatic ischemia-reperfusion injury by suppressing HMGB1-dependent GSDMD-mediated kupffer cells pyroptosis. Int. Immunopharmacol. 2019, 68, 145-155. [CrossRef]

126. Zhang, H.-L.; Dai, L.-H.; Wu, Y.-H.; Yu, X.-P.; Zhang, Y.-Y.; Guan, R.-F.; Liu, T.; Zhao, J.J.B.; Bulletin, P. Evaluation of hepatocyteprotective and anti-hepatitis B virus properties of Cichoric acid from Cichorium intybus leaves in cell culture. Biol. Pharm. Bull. 2014, 37, 1214-1220. [CrossRef] [PubMed]

127. Bruck, R.; Ashkenazi, M.; Weiss, S.; Goldiner, I.; Shapiro, H.; Aeed, H.; Genina, O.; Helpern, Z.; Pines, M. Prevention of liver cirrhosis in rats by curcumin. Liver Int. 2007, 27, 373-383. [CrossRef]

128. Kang, M.-C.; Kang, S.-M.; Ahn, G.; Kim, K.-N.; Kang, N.; Samarakoon, K.W.; Oh, M.-C.; Lee, J.-S.; Jeon, Y.-J. Protective effect of a marine polyphenol, dieckol against carbon tetrachloride-induced acute liver damage in mouse. Environ. Toxicol. Pharmacol. 2013, 35, 517-523. [CrossRef]

129. Ma, J.Q.; Ding, J.; Zhao, H.; Liu, C.M. Puerarin attenuates carbon tetrachloride-induced liver oxidative stress and hyperlipidaemia in mouse by JNK/c-Jun/CYP7A1 pathway. Basic Clin. Pharmacol. Toxicol. 2014, 115, 389-395. [CrossRef]

130. Calland, N.; Sahuc, M.-E.; Belouzard, S.; Pène, V.; Bonnafous, P.; Mesalam, A.A.; Deloison, G.; Descamps, V.; Sahpaz, S.; Wychowski, C. Polyphenols inhibit hepatitis C virus entry by a new mechanism of action. J. Virol. 2015, 89, 10053-10063. [CrossRef]

131. Rasool, M.K.; Sabina, E.P.; Ramya, S.R.; Preety, P.; Patel, S.; Mandal, N.; Mishra, P.P.; Samuel, J. Pharmacology, Hepatoprotective and antioxidant effects of gallic acid in paracetamol-induced liver damage in mice. J. Pharm. Ther. 2010, 62, 638-643.

132. Sun, H.; Che, Q.-M.; Zhao, X.; Pu, X.-P. Antifibrotic effects of chronic baicalein administration in a CCl4 liver fibrosis model in rats. Eur. J. Pharmacol. 2010, 631, 53-60. [CrossRef] [PubMed]

133. Zhang, Z.-F.; Zhang, Y.-Q.; Fan, S.-H.; Zhuang, J.; Zheng, Y.-L.; Lu, J.; Wu, D.-M.; Shan, Q.; Hu, B. Troxerutin protects against 2, 2', 4, $4^{\prime}$-tetrabromodiphenyl ether (BDE-47)-induced liver inflammation by attenuating oxidative stress-mediated NAD+-depletion. J. Hazard. Mater. 2015, 283, 98-109. [CrossRef]

134. Ren, J.; Fan, C.; Chen, N.; Huang, J.; Yang, Q. Resveratrol pretreatment attenuates cerebral ischemic injury by upregulating expression of transcription factor Nrf2 and HO-1 in rats. Neurochem. Res. 2011, 36, 2352-2362. [CrossRef] [PubMed]

135. Hussein, R.M.; Mohamed, W.R.; Omar, H.A. A neuroprotective role of kaempferol against chlorpyrifos-induced oxidative stress and memory deficits in rats via GSK3 $\beta-N r f 2$ signaling pathway. Pestic. Biochem. Physiol. 2018, 152, 29-37. [CrossRef] [PubMed]

136. Xiao, G.; Lyu, M.; Wang, Y.; He, S.; Liu, X.; Ni, J.; Li, L.; Fan, G.; Han, J.; Gao, X. Ginkgo Flavonol Glycosides or Ginkgolides Tend to Differentially Protect Myocardial or Cerebral Ischemia-Reperfusion Injury via Regulation of TWEAK-Fn14 Signaling in Heart and Brain. Front. Pharmacol. 2019, 10, 735. [CrossRef]

137. Song, Z.; Han, S.; Pan, X.; Gong, Y.; Wang, M. Pharmacology, Pterostilbene mediates neuroprotection against oxidative toxicity via oestrogen receptor $\alpha$ signalling pathways. J. Pharm. Pharmacol. 2015, 67, 720-730. [CrossRef]

138. Chen, P.; Lin, X.; Yang, C.-H.; Tang, X.; Chang, Y.-W.; Zheng, W.; Luo, L.; Xu, C.; Chen, Y.-H. Study on chemical profile and neuroprotective activity of Myrica rubra leaf extract. Molecules 2017, 22, 1226. [CrossRef]

139. Pegorini, S.; Braida, D.; Verzoni, C.; Guerini-Rocco, C.; Consalez, G.G.; Croci, L.; Sala, M. Capsaicin exhibits neuroprotective effects in a model of transient global cerebral ischemia in Mongolian gerbils. Br. J. Pharmacol. 2005, 144, 727-735. [CrossRef]

140. Koh, S.S.; Ooi, S.C.-Y.; Lui, N.M.-Y.; Qiong, C.; Ho, L.T.-Y.; Cheah, I.K.-M.; Halliwell, B.; Herr, D.R.; Ong, W.-Y. Effect of ergothioneine on 7-ketocholesterol-induced endothelial injury. Neuromol. Med. 2021, 23, 184-198. [CrossRef]

141. Wang, J.; Li, P.; Qin, T.; Sun, D.; Zhao, X.; Zhang, B. Protective effect of epigallocatechin-3-gallate against neuroinflammation and anxiety-like behavior in a rat model of myocardial infarction. Brain Behav. 2020, 10, e01633. [CrossRef]

142. Mammana, S.; Cavalli, E.; Gugliandolo, A.; Silvestro, S.; Pollastro, F.; Bramanti, P.; Mazzon, E. Could the combination of two non-psychotropic cannabinoids counteract neuroinflammation? Effectiveness of cannabidiol associated with cannabigerol. Medicina 2019, 55, 747. [CrossRef]

143. Amann, K.; Boor, P.; Wiech, T.; Singh, J.; Vonbrunn, E.; Knöll, A.; Hermann, M.; Büttner-Herold, M.; Daniel, C.; Hartmann, A. COVID-19 effects on the kidney. Pathology 2021, 42, 183-187.

144. Chan, L.; Chaudhary, K.; Saha, A.; Chauhan, K.; Vaid, A.; Zhao, S.; Paranjpe, I.; Somani, S.; Richter, F.; Miotto, R. AKI in hospitalized patients with COVID-19. J. Am. Soc. Nephrol. 2021, 32, 151-160. [CrossRef]

145. Benedetti, C.; Waldman, M.; Zaza, G.; Riella, L.V.; Cravedi, P. COVID-19 and the kidneys: An update. Front. Med. (Lausanne) 2020, 7, 423. [CrossRef]

146. Sfera, A.; Osorio, C.; Jafri, N.; Diaz, E.L.; Campo Maldonado, J.E. Intoxication with endogenous angiotensin II: A COVID-19 hypothesis. Front. Immunol. 2020, 11, 1472. [CrossRef] [PubMed]

147. de Queiroz, T.M.; Lakkappa, N.; Lazartigues, E. ADAM17-mediated shedding of inflammatory cytokines in hypertension. Front. Pharmacol. 2020, 11, 1154. [CrossRef] [PubMed]

148. Larsen, C.P.; Bourne, T.D.; Wilson, J.D.; Saqqa, O.; Sharshir, M.A. Collapsing glomerulopathy in a patient with COVID-19. Kidney Int. Rep. 2020, 5, 935-939. [CrossRef] [PubMed] 
149. Kissling, S.; Rotman, S.; Gerber, C.; Halfon, M.; Lamoth, F.; Comte, D.; Lhopitallier, L.; Sadallah, S.; Fakhouri, F. Collapsing glomerulopathy in a COVID-19 patient. Kidney Int. 2020, 98, 228-231. [CrossRef] [PubMed]

150. Su, H.; Yang, M.; Wan, C.; Yi, L.-X.; Tang, F.; Zhu, H.-Y.; Yi, F.; Yang, H.-C.; Fogo, A.B.; Nie, X. Renal histopathological analysis of 26 postmortem findings of patients with COVID-19 in China. Kidney Int. 2020, 98, 219-227. [CrossRef]

151. Li, Z.; Wu, M.; Yao, J.; Guo, J.; Liao, X.; Song, S.; Li, J.; Duan, G.; Zhou, Y.; Wu, X. Caution on kidney dysfunctions of COVID-19 patients. MedRxiv 2020. [CrossRef]

152. Chen, J.; Wang, W.; Tang, Y.; Huang, X.-R.; Yu, X.; Lan, H.-Y. Inflammatory stress in SARS-COV-2 associated Acute Kidney Injury. Int. J. Biol. Sci. 2021, 17, 1497. [CrossRef] [PubMed]

153. Ferreira-Gomes, M.; Kruglov, A.; Durek, P.; Heinrich, F.; Tizian, C.; Heinz, G.A.; Pascual-Reguant, A.; Du, W.; Mothes, R.; Fan, C. SARS-CoV-2 in severe COVID-19 induces a TGF- $\beta$-dominated chronic immune response that does not target itself. Nat. Commun. 2021, 12, 1-14. [CrossRef]

154. Gu, Y.-Y.; Zhang, M.; Cen, H.; Wu, Y.-F.; Lu, Z.; Lu, F.; Liu, X.-S.; Lan, H.-Y. Quercetin as a potential treatment for COVID-19induced acute kidney injury: Based on network pharmacology and molecular docking study. PLoS ONE 2021, 16, e0245209. [CrossRef] [PubMed]

155. Tan, R.Z.; Wang, C.; Deng, C.; Zhong, X.; Yan, Y.; Luo, Y.; Lan, H.Y.; He, T.; Wang, L. Quercetin protects against cisplatin-induced acute kidney injury by inhibiting Mincle/Syk/NF-kB signaling maintained macrophage inflammation. Phytother. Res. 2020, 34, 139-152. [CrossRef] [PubMed]

156. Lippi, G.; Plebani, M.J.C.C.; Medicine, L. Laboratory abnormalities in patients with COVID-2019 infection. Clin. Chem. Lab. Med. 2020, 58, 1131-1134. [CrossRef]

157. Arentz, M.; Yim, E.; Klaff, L.; Lokhandwala, S.; Riedo, F.X.; Chong, M.; Lee, M. Characteristics and outcomes of 21 critically ill patients with COVID-19 in Washington State. JAMA 2020, 323, 1612-1614. [CrossRef] [PubMed]

158. Madjid, M.; Safavi-Naeini, P.; Solomon, S.D.; Vardeny, O. Potential effects of coronaviruses on the cardiovascular system: A review. JAMA Cardiol. 2020, 5, 831-840. [CrossRef]

159. Bansal, M. Cardiovascular disease and COVID-19. Diabetes Metab. Syndr. 2020, 14, 247-250. [CrossRef] [PubMed]

160. Liu, Q.; Tian, J.; Xu, Y.; Li, C.; Meng, X.; Fu, F. Protective effect of RA on myocardial infarction-induced cardiac fibrosis via AT1R/p38 MAPK pathway signaling and modulation of the ACE2/ACE ratio. J. Agric. Food Chem. 2016, 64, 6716-6722. [CrossRef] [PubMed]

161. Wang, Z.; Pang, W.; He, C.; Li, Y.; Jiang, Y.; Guo, C. Blueberry anthocyanin-enriched extracts attenuate fine particulate matter (PM2. 5)-induced cardiovascular dysfunction. J. Agric. Food Chem. 2017, 65, 87-94. [CrossRef]

162. Escudero-López, B.; Berná, G.; Ortega, Á.; Herrero-Martín, G.; Cerrillo, I.; Martín, F.; Fernández-Pachón, M.-S. Consumption of orange fermented beverage reduces cardiovascular risk factors in healthy mice. Food Chem. Toxicol. 2015, 78, 78-85. [CrossRef] [PubMed]

163. Sa-Ngiamsuntorn, K.; Suksatu, A.; Pewkliang, Y.; Thongsri, P.; Kanjanasirirat, P.; Manopwisedjaroen, S.; Charoensutthivarakul, S.; Wongtrakoongate, P.; Pitiporn, S.; Chaopreecha, J. Anti-SARS-CoV-2 activity of Andrographis paniculata extract and its major component Andrographolide in human lung epithelial cells and cytotoxicity evaluation in major organ cell representatives. J. Nat. Prod. 2021, 84, 1261-1270. [CrossRef]

164. Wang, B.; Kovalchuk, A.; Li, D.; Rodriguez-Juarez, R.; Ilnytskyy, Y.; Kovalchuk, I.; Kovalchuk, O. In search of preventive strategies: Novel high-CBD Cannabis sativa extracts modulate ACE2 expression in COVID-19 gateway tissues. Aging 2020, 12, 22425-22444. [PubMed]

165. Orlando, G.; Chiavaroli, A.; Adorisio, S.; Delfino, D.V.; Brunetti, L.; Recinella, L.; Leone, S.; Zengin, G.; Acquaviva, A.; Angelini, P. Unravelling the Phytochemical Composition and the Pharmacological Properties of an Optimized Extract from the Fruit from Prunus mahaleb L.: From Traditional Liqueur Market to the Pharmacy Shelf. Molecules 2021, 26, 4422. [CrossRef] [PubMed]

166. Gandhi, S.; Srivastava, A.K.; Ray, U.; Tripathi, P.P. Is the collapse of the respiratory center in the brain responsible for respiratory breakdown in COVID-19 patients? ACS Chem. Neurosci. 2020, 11, 1379-1381. [CrossRef]

167. Al-Ramadan, A.; Rabab'h, O.; Shah, J.; Gharaibeh, A. Acute and post-acute neurological complications of COVID-19. Neurol. Int 2021, 13, 102-119. [CrossRef] [PubMed]

168. Chen, N.; Zhou, M.; Dong, X.; Qu, J.; Gong, F.; Han, Y.; Qiu, Y.; Wang, J.; Liu, Y.; Wei, Y. Epidemiological and clinical characteristics of 99 cases of 2019 novel coronavirus pneumonia in Wuhan, China: A descriptive study. Lancet 2020, 395, 507-513. [CrossRef]

169. Huang, C.; Wang, Y.; Li, X.; Ren, L.; Zhao, J.; Hu, Y.; Zhang, L.; Fan, G.; Xu, J.; Gu, X. Clinical features of patients infected with 2019 novel coronavirus in Wuhan, China. Lancet 2020, 395, 497-506. [CrossRef]

170. Mao, L.; Jin, H.; Wang, M.; Hu, Y.; Chen, S.; He, Q.; Chang, J.; Hong, C.; Zhou, Y.; Wang, D. Neurologic manifestations of hospitalized patients with coronavirus disease 2019 in Wuhan, China. JAMA Neurol. 2020, 77, 683-690. [CrossRef] [PubMed]

171. Li, Y.; Li, M.; Wang, M.; Zhou, Y.; Chang, J.; Xian, Y.; Wang, D.; Mao, L.; Jin, H.; Hu, B. Acute cerebrovascular disease following COVID-19: A single center, retrospective, observational study. Stroke Vasc. Neurol. 2020, 5, 279-284. [CrossRef] [PubMed]

172. Scullen, T.; Keen, J.; Mathkour, M.; Dumont, A.S.; Kahn, L. Coronavirus 2019 (COVID-19)-associated encephalopathies and cerebrovascular disease: The New Orleans experience. World Neurosurg. 2020, 141, e437-e446. [CrossRef] [PubMed]

173. Pedersen, S.F.; Ho, Y.-C. SARS-CoV-2: A storm is raging. J. Clin. Investig. 2020, 130, 2202-2205. [CrossRef] [PubMed] 
174. Gutiérrez-Ortiz, C.; Méndez-Guerrero, A.; Rodrigo-Rey, S.; San Pedro-Murillo, E.; Bermejo-Guerrero, L.; Gordo-Mañas, R.; de Aragón-Gómez, F.; Benito-León, J. Miller Fisher Syndrome and polyneuritis cranialis in COVID-19. Neurology 2020, 95, e601-e605. [CrossRef]

175. Taquet, M.; Geddes, J.R.; Husain, M.; Luciano, S.; Harrison, P. 6-month neurological and psychiatric outcomes in 236379 survivors of COVID-19: A retrospective cohort study using electronic health records. Lan Psychy. 2021, 8, 416-427. [CrossRef]

176. Rajkumar, R.P. Ayurveda and COVID-19: Where psychoneuroimmunology and the meaning response meet. Brain. Behav. Immun. 2020, 87, 8-9. [CrossRef]

177. Kempuraj, D.; Thangavel, R.; Kempuraj, D.D.; Ahmed, M.E.; Selvakumar, G.P.; Raikwar, S.P.; Zaheer, S.A.; Iyer, S.S.; Govindarajan, R.; Chandrasekaran, P.N. Neuroprotective effects of flavone luteolin in neuroinflammation and neurotrauma. Biofactors 2021, 47, 190-197. [CrossRef]

178. Theoharides, T.; Conti, P. COVID-19 and multisystem inflammatory syndrome, or is it mast cell activation syndrome. J. Biol. Regul. Homeost. Agents 2020, 34, 1633-1636. [PubMed]

179. Martinez, M.A.; Franco, S. Impact of COVID-19 in liver disease progression. Hepatol. Commun. 2021, 5, 1138-1150. [CrossRef]

180. Bertolini, A.; van de Peppel, I.P.; Bodewes, F.; Moshage, H.; Fantin, A.; Farinati, F.; Fiorotto, R.; Jonker, J.W.; Strazzabosco, M.; Verkade, H. Abnormal liver function tests in patients with COVID-19: Relevance and potential pathogenesis. Hepatology 2020, 72 , 1864-1872. [CrossRef] [PubMed]

181. Phipps, M.M.; Barraza, L.H.; LaSota, E.D.; Sobieszczyk, M.E.; Pereira, M.R.; Zheng, E.X.; Fox, A.N.; Zucker, J.; Verna, E.C. Acute liver injury in COVID-19: Prevalence and association with clinical outcomes in a large US cohort. Hepatology 2020, 72, 807-817. [CrossRef] [PubMed]

182. Zhang, C.; Shi, L.; Wang, F.-S. Liver injury in COVID-19: Management and challenges. Lancet Gastroenterol. Hepatol. 2020, 5, 428-430. [CrossRef]

183. Zhao, B.; Ni, C.; Gao, R.; Wang, Y.; Yang, L.; Wei, J.; Lv, T.; Liang, J.; Zhang, Q.; Xu, W.; et al. Recapitulation of SARS-CoV-2 infection and cholangiocyte damage with human liver ductal organoids. Protein Cell. 2020, 11, 771-775. [CrossRef] [PubMed]

184. Wang, Y.; Liu, S.; Liu, H.; Li, W.; Lin, F.; Jiang, L.; Li, X.; Xu, P.; Zhang, L.; Zhao, L. SARS-CoV-2 infection of the liver directly contributes to hepatic impairment in patients with COVID-19. J. Hepatol. 2020, 73, 807-816. [CrossRef]

185. Goldman, J.D.; Lye, D.C.; Hui, D.S.; Marks, K.M.; Bruno, R.; Montejano, R.; Spinner, C.D.; Galli, M.; Ahn, M.-Y.; Nahass, R.G.; et al. Remdesivir for 5 or 10 days in patients with severe Covid-19. N. Engl. J. Med. 2020, 383, 1827-1837. [CrossRef]

186. Hernandez, A.V.; Roman, Y.M.; Pasupuleti, V.; Barboza, J.J.; White, C.M. Hydroxychloroquine or chloroquine for treatment or prophylaxis of COVID-19: A living systematic review. Ann. Intern. Med. 2020, 173, 287-296. [CrossRef]

187. Hodgman, M.J.; Garrard, A.R. A review of acetaminophen poisoning. Crit. Care Clin. 2012, 28, 499-516. [CrossRef]

188. Li, H.; Hu, Y.; Tang, H.; Li, S.; Ding, H.; Zhai, S.; Zhao, R. The Potential of Glycyrrhizinate in the Management of COVID-19: A Systematic Review of the Efficacy and Safety of Glycyrrhizin Preparations in the Treatment of SARS and MERS. Am. J. Chin. Med. 2020, 48, 1539-1552. [CrossRef] [PubMed]

189. Liao, F.L.; Peng, D.H.; Chen, W.; Hu, H.N.; Tang, P.; Liu, Y.Y.; Luo, Y.; Yao, T. Evaluation of serum hepatic enzyme activities in different COVID-19 phenotypes. J. Med. Virol. 2021, 93, 2365-2373. [CrossRef] [PubMed]

190. Tan, R.; Xiang, X.; Chen, W.; Yang, Z.; Hu, W.; Qu, H.; Liu, J. Efficacy of diammonium glycyrrhizinate combined with vitamin C for treating hospitalized COVID-19 patients: A retrospective, observational study. QJM Int. J. Med. 2021. [CrossRef]

191. Roshdy, W.H.; Rashed, H.A.; Kandeil, A.; Mostafa, A.; Moatasim, Y.; Kutkat, O.; Abo Shama, N.M.; Gomaa, M.R.; El-Sayed, I.H.; El Guindy, N.M. EGYVIR: An immunomodulatory herbal extract with potent antiviral activity against SARS-CoV-2. PLoS ONE 2020, 15, e0241739. [CrossRef]

192. Storz, M.A. Lifestyle Adjustments in Long-COVID Management: Potential Benefits of Plant-Based Diets. Curr. Nutr. Rep. 2021, 1-12. [CrossRef]

193. Girija, P.; Sivan, N. Ayurvedic treatment of COVID-19/SARS-CoV-2: A case report. J. Ayurveda Integr. Med. 2020, in press. [CrossRef] [PubMed]

194. Huang, Z.; Fu, F.; Ye, H.; Gao, H.; Tan, B.; Wang, R.; Lin, N.; Qin, L.; Chen, W. Chinese herbal Huo-Gu formula for the treatment of steroid-associated osteonecrosis of femoral head: A 14-year follow-up of convalescent SARS patients. J. Orthop. Translat. 2020, 23, 122-131. [CrossRef] [PubMed] 